\title{
Raw Materials Synthesis from Heavy Metal Industry Effluents with Bioremediation and Phytomining: A Biomimetic Resource Management Approach
}

\author{
Salmah B. Karman, ${ }^{1,2}$ S. Zaleha M. Diah, ${ }^{1}$ and Ille C. Gebeshuber ${ }^{1,3}$ \\ ${ }^{1}$ Institute of Microengineering and Nanoelectronics, Universiti Kebangsaan Malaysia, 43600 Bangi, Malaysia \\ ${ }^{2}$ Department of Biomedical Engineering, Faculty of Engineering, University of Malaya, 50603 Kuala Lumpur, Malaysia \\ ${ }^{3}$ Institute of Applied Physics, Vienna University of Technology, Wiedner Hauptstraße 8-10/134, 1040 Vienna, Austria \\ Correspondence should be addressed to Ille C. Gebeshuber; gebeshuber@iap.tuwien.ac.at
}

Received 17 July 2014; Accepted 5 September 2014

Academic Editor: George Z. Kyzas

Copyright (C) 2015 Salmah B. Karman et al. This is an open access article distributed under the Creative Commons Attribution License, which permits unrestricted use, distribution, and reproduction in any medium, provided the original work is properly cited.

\begin{abstract}
Heavy metal wastewater poses a threat to human life and causes significant environmental problems. Bioremediation provides a sustainable waste management technique that uses organisms to remove heavy metals from contaminated water through a variety of different processes. Biosorption involves the use of biomass, such as plant extracts and microorganisms (bacteria, fungi, algae, yeast), and represents a low-cost and environmentally friendly method of bioremediation and resource management. Biosorptionbased biosynthesis is proposed as a means of removing heavy metals from wastewaters and soils as it aids the development of heavy metal nanoparticles that may have an application within the technology industry. Phytomining provides a further green method of managing the metal content of wastewater. These approaches represent a viable means of removing toxic chemicals from the effluent produced during the process of manufacturing, and the bioremediation process, furthermore, has the potential to save metal resources from depletion. Biomimetic resource management comprises bioremediation, biosorption, biosynthesis, phytomining, and further methods that provide innovative ways of interpreting waste and pollutants as raw materials for research and industry, inspired by materials, structures, and processes in living nature.
\end{abstract}

\section{Introduction}

Heavy metals are hazardous and dangerous, especially when introduced into the environment via pollution. However, they do have a valuable role to play; for example, heavy metal nanoparticles are used in various nanoscience and nanotechnology applications. Biomimetic resource management refers to a way of dealing with resources that is inspired by living nature regarding materials, structures, and processes. Such an approach offers innovative new ways to deal with heavy metal-loaded waste effluents and provides raw materials for industry. Plants and microorganisms are used to redefine "waste" to "revenue" for new industries [1]. Heavy metalloaded effluents from industry could be the base material for metallic nanoparticles used in nanoscience and nanotechnology. Plants (such as the sunflower plant) and microorganisms (such as bacteria, fungi, algae, and yeast) can be used to accumulate these heavy metals and to safely remove the pollutants from the water and the soil. The first goal regarding heavy metal effluents should be their prevention. However, in cases where they cannot (yet) be completely prevented, biomimetics can come into the game: we could learn from living nature how to deal with such effluents not by treating them as waste but by treating them as resource (waste-towealth concept). Metallic nanoparticles are currently used in important nanotechnology research areas and are also heavily used in applications. They are important (and acceptable) in our current early phases of nanotechnology research and development, where we need to understand the basics. Future resource management might increasingly realize the paramount biomimetic principle of "shape rather than material" to achieve functionalities that are currently fulfilled by unsustainable metal- and plastic-based resources by benign materials that would allow for sustainable engineering. Apart 
from biomineralized structures and specific biomolecules, where the chemistry (as opposed to the physics) of the metal is necessary for the function (such as in hemoglobin or chlorophyll), living nature rarely uses metals. In most cases, elaborated structures from hierarchically composed metal free materials yield the functionality that we, with our current conventional engineering, mainly achieve with the use of many different materials, including metals.

The main purpose of this paper is to explore the potential of using heavy metals that are extracted from the environment with the help of organisms as a resource for metallic nanoparticles. This has a number of potential benefits. The particles are removed from the environment and research, development, and industry are provided with a novel source of nanoparticles and their constituents. Since some nanoparticles can be derived directly from natural sources, such as plants and microorganisms, they can be accessed at a lower cost and in a more biofriendly manner than those fabricated via conventional production mechanisms. Another advantage of extracting heavy metals from the environment is that the natural nanoparticles accessed via this method exhibit reproducible shapes and sizes, whereas such shape and size uniformity remains a challenge in man-made nanoparticles. A variety of physical and chemical procedures are used for the synthesis of metallic nanoparticles, with "bottom-up" and "top-down" approaches as two broad categories.

This review predominantly concentrates on the management and recovery of heavy metals from industrial wastewater through the application of a biosorption-desorption process. The production of metal nanoparticles from heavy metal industrial effluent is also discussed. A particular focus will be placed on the bioremediation process, since this method holds great promise as a potential technique of biosynthesizing metal nanoparticles from polluted heavy metal industrial effluent. It is envisaged that developments in this area provide a means of removing toxic effluent from wastewater and/or soil and also represent a viable and sustainable technique for obtaining nanoparticles for high technology applications in a manner that is environmentally friendly and cost effective.

\section{The Bioremediation Process as an Approach for Designing Materials for Environmental Applications}

In order to ensure that industrial practices are sustainable on a long-term basis, it is critical that we develop an awareness of the environment and the ecological effects of manufacturing techniques that produce toxic metals. Contaminated soil in the environment as a result of manufacturing practices is common throughout the world. Numerous countries face issues as a result of contaminated wastewater and have taken action to raise awareness via relevant policies and the development of technologies [2]. However, many of the physiochemical processes that are traditionally employed in the remediation of soils and polluted sites are expensive and do not permanently alleviate hazardous pollution [3]. Bioremediation represents one method of using biological systems, such as microorganisms or microbial-like bacteria, fungi, and other agents, to clean up and degrade organic and inorganic pollutants [4]. Bioremediation is a general concept that encompasses all the processes and actions required to biotransform an environment in which contaminants exist back into its original pristine condition. Various factors are involved in the bioremediation process and this process uses various agents, such as bacteria, yeast, fungi, algae, and higher plants, as major tools to treat oil spills and remove heavy metals from the environment [5]. A number of sophisticated technologies for the remediation of polluted sites are currently in use.

2.1. The Bioremediation Process: Current Situation. Effluents produced by the metal industry are often found as contaminants in water sources, rivers, seas, and soils. Fu and Wang [6] published a review on the use of bioremediation to remove heavy metal ions from wastewaters; remediation technologies used to treat heavy metal contaminated groundwater were summarized by Hashim et al. [7]. Heavy metals are defined as metals that have an atomic weight between 63.5 and 200.6 and a specific gravity greater than 5 [7]. They include Zinc, Copper, Nickel, Mercury, Cadmium, Lead, Chromium Arsenic, Silver, Platinum, and Gold [6]. Some heavy metals are toxic and poisonous, especially to humans, while noble metals are very valuable and can be used in high-tech nanotechnology applications or in the production of highvalue goods.

The management of toxic heavy metals that are introduced into the environment via industrial wastewater is very important, as toxic wastewaters pose serious threats to the environment and to human health [8]. The technologies that are currently used in the commercial remediation of heavy metal effluent rely on immobilizing the heavy metal by leachability [9]. Those techniques include chemical fixation, chemical alteration/complexation, stabilisation, capping, soil washing, and ferric iron remediation stabilisation. Additional methods that are currently being used to remediate heavy metal contamination are chemical precipitation, ion exchange, adsorption, membrane filtration, electrochemical treatment technologies, floatation, coagulation, and flocculation [6]. Each method has its own advantages and limitations. The chemical precipitation, ion exchange, and membrane filtration methods are widely used for wastewater remediation with high efficiency. In the chemical precipitation method, the heavy metal ion is altered by changing it from a soluble to an insoluble substance so that it can later be removed via a process of flocculation and sedimentation. Through a combination of chemical precipitation and nanofiltration methods, it is possible to recover heavy metal ions for reuse.

The main limitations of these methods are that they are costly, involve complex processes, and are environmentally unfriendly. For example, the ion exchange method is expensive and the chemical handling process it employs could cause secondary pollution. Even though the use of natural resin, zeolites, is low-cost and environmentally friendly and offers the same performance as synthetic resin, its availability is limited and, at present, its use is limited to the experimental laboratory only. 
The adsorption process has long been recognized as a low-cost alternative to the removal of contaminants from wastewater. This flexible, low-cost method works even in wastewater that contains a low concentration of metal effluents. However, the efficiency of this method varies according to the type of adsorbents, since certain sorbents have high selectivity towards heavy metals.

In commercial adsorption-based remediation processes, commercial activated Carbon (AC) is widely used as a high efficiency absorbent [6]. However, the price of AC is increasing. Furthermore, when used as absorbents, Carbon nanotubes, for example, pose a risk to humans when they are discharged into the water. To avoid various limitations, especially the risk to humans, there is a need to identify a means of improving this method so that it is more environmentally friendly and of zero risk to life forms. Furthermore, as a result of the rapid growth of industrialization, which has increased the volume of heavy metal pollution, there is a need to identify a low-cost method of removing contaminants from wastewater. Biology-based remediation processes are attractive because they have lower operation costs than physicochemical processes [10]. Thus, the use of biological materials for absorption holds great promise as they are highly cost effective and environmentally benign. As such, a large amount of research has been conducted into the use of biological materials for the absorption of heavy metals in wastewater with much of this research placing a particular emphasis on the types of biosorbents that are available.

Biosorbents from living cells, dead cells, or biomass are the key components in biosorption technology and, for the last 20 years, various researchers have focused on these materials [10]. As reported by Atkinson et al. [10], the earliest investigation into microbial biomass as a biosorbent was performed in the 1980s, potentially earlier. Current studies on bacterial biosorbents for the bioremediation of heavy metals were reviewed by Dhankhar and Guriyan [11] and Vijayaraghavan and Yun [12]. Studies on marine algae as biosorbents were comprehensively reviewed by He and Chen [13]. Bankar et al. [14] and Viraraghavan and Srinivasan [15], respectively, discussed recent reviews on yeasts and fungalbased biosorption. Studies on biomass from agricultural waste and byproducts for the removal of heavy metals have become a new interest in recent years [16-18].

2.1.1. Removing Heavy Metals. Heavy metals are present in soil, aqueous solution, or streams as the result of a variety of human waste activities, which include intensive agriculture, sludge dumping, metal-rich mine tailings, metal smelting, electroplating, energy conversion, and fuel production [19]. All heavy metals have a toxic effect if they are found in high concentrations in soil and therefore need to be removed or transformed. Microorganisms can be used as cation sorbents for the removal of heavy metal cations from industrial wastewater or for the recovery of metals from their solutions [20]. Dave and Chopda [21] described how a surface modification strategy could enhance the stability and efficiency of iron oxide nanomaterials in the removal of heavy metals for remediation in water. Metal oxide nanoparticles as antimicrobial additives have been the subject of extensive research
[22]. Ahluwalia and Goyal [23] described the removal of heavy metals such as Lead, Zinc, Cadmium, Chromium, Copper, and Nickel from wastewater through the use of microbial and plant-derived biomass of Aspergillus niger, Penicilium chrysogenum, Rhizophus nigricans, Ascophyllum nodosum, Sargassum natans, Chrorella fusca, Oscillatoria anguistissima, Basillus firmus, and Streptomyces sp. The ability of algae to remove heavy metals from aqueous solution has been recognized for some decades. Li and coworkers [24] carried out an experiment using the yeasts Zygosaccharomyces rouxii and Saccharomyces cerevisiae in Cadmium removal in a complex food environment. Their results indicated that $Z$. rouxii had a powerful Cadmium removal ability at low Cadmium concentrations, which mainly depended on the intracellular Cadmium bioaccumulation. The percentage of intracellular Cadmium bioaccumulation of both Z rouxii and $S$. cerevisiae decreased as the initial biomass and Cadmium concentrations increased. The metal content of algae can be used to predict the level of metal pollution in a water body [25]. The high accumulation capacity can even be used for the enrichment or recycling of valuable metals. Their relative comparison is generally made using an accumulation factor $(\mathrm{AF})$. The metal accumulation factor (AF) is defined as the ratio of metal concentration in plant cells $(\mu \mathrm{g} / \mathrm{g})$ and the metal concentration in water $(\mu \mathrm{g} / \mathrm{mL})$ and it is also known as bioconcentration ratio, concentration ratio, or enrichment ratio. Toxic metals can be transferred to their surroundings or to the wider environment through numerous ways including industrial production processes, incineration emissions, and waste disposal. The majority of deposition of metals in the environment is within soil or sediment. Microorganisms can detoxify metals by valence transformation, extracellular chemical precipitation, or volatilization, through which they enzymatically reduce some metals through metabolic processes [26] (Table 1). New technologies to improve the remediation process are continually being developed and adopted and a system known as "pump-and-treat" has been established; however, this is time consuming and inefficient [27].

2.1.2. Phytoremediation. Phytoremediation technology can be applied as a solution to the major environmental and human hazards caused by contaminated soils and waters [31]. Phytoremediation involves the use of various green plant species to clean up, remove, or detoxify environmental contaminants or to render them harmless [31-33]. Phytoremediation is potentially the best practice for removing pollutants, is very promising as an environmental technology, and can be employed at a lower cost than conventional or alternative methods. Phytoremediation technologies are quite successful in their ability to clean up waste solutions. The phytoremediation approach exploits the ability of various plant species to remove heavy metals from the environment and then accumulate a large amount of toxic metals. The green plant species required to be effective in phytoremediation typically needs to grow rapidly, produce large quantities of biomass, have deep roots and easily harvested shoots, and have the potential to accumulate high concentrations of contaminants in these shoots. The advantages of this method 
TABLE 1: Organisms that remove heavy metal from waste (selection).

\begin{tabular}{lllc}
\hline Element & Waste from ... & Organisms & Mechanism \\
\hline Copper [28] & Electronic waste & Leaf extract weed Lantana camara & Bind and remove \\
Copper [28] & Electronic waste & Fusarium and Pseudomonas & Nanozinc oxide biocomposite \\
Arsenic & Water & Lactobacillus acidophilus & Biosorption \\
Chromium (IV) [29] & Aqueous solution & Guar gum & Intracellular cross \\
Chromium (IV) [30] & Aqueous solution & Seaweed biomass Acanthophora spicifera & Yeast Zygosaccharomyces rouxii and \\
Cadmium (Cd) & Food environment & Saccharomyces cerevisiae & . \\
\hline
\end{tabular}

compared to the existing remediation techniques are that they involve minimal site destruction and destabilization, have a low environmental impact, and are aesthetically favorable [19].

One important characteristic of phytoremediation is phytoextraction. Phytoextraction technology involves the reduction of metal concentration in the soil through the cultivation of plants that have a high capacity for metal accumulation in the shoots or that are capable of uptaking the metal from the contaminated soil via the plant root. Phytoextraction technology is a plant-based technology that cleans heavy metal from the soil through the process of hyperaccumulation [34]. This technology is used to achieve better environmental protection with a sustainable metal source and is based on the hyperaccumulation of metals into the whole plants [35]. Two categories of plants can be used for phytoextraction: small plants that have high foliar metal concentration but slow growth rates that do not provide a high annual biomass (such as Thlaspi caerulescens) and high biomass crops which have a large biomass production but take up lower metal concentrations (such as Brassica juncea). Gupta and coworkers [36] used Phaseolus vulgaris var. T55 for the phytoextraction of heavy metals from flash ash (byproduct of combustion of coal). The capability of the plants to reduce the amount of heavy metals present in contaminated soils depends on plant biomass production and their metal bioaccumulation factor. The bioaccumulation factor is the ratio of metal concentration present in the shoot tissue of the roots to the one of the soil. It can be determined by the ability and capacity of the roots to take up metals and transfer them to the xylem through the mass flow in xylem by transpiration and their ability to accumulate, store, and detoxify metals while maintaining metabolism, growth, and biomass production [37].

2.2. Characterization of Metal Biosorption Mechanisms. The biological interaction between biological cells and metal ions has potential in the production of metal nanoparticles or metal compounds. These processes are very popular in the bioremediation of soil and water sources that have been contaminated by heavy metal effluent [7]. The detailed features of the metal nanoparticles were obtained and the performance of the process depends on the respective type of biological cells and metal ions [12]. The interaction processes that are involved include biosorption, accumulation, and bioreduction $[7,12]$.
The mechanism for binding metals to the walls of bacterial cells consists of three steps: (i) ion exchange reactions with peptidoglycan and teichoic acid, (ii) precipitation through nucleation reactions, and (iii) complexation with nitrogen and oxygen ligands $[38,39]$.

The bioaccumulation process is the use of metabolic activity of a living organism to remove heavy metal from a given environment $[12,40]$.

The biosorption process involves the extracellular passive binding of a metal to a nonliving biomass in an aqueous solution. Two types of approaches commonly used are biosorption without enzyme (a.k.a. protein capping) and biosorption with capping of enzyme. Biosorption has already been investigated for the decontamination of heavy metal pollution solutions [41]. Biosorption technology provides one potential biological approach to cleaning heavy metal industrial wastewater [10]. A number of review papers have discussed the use of biosorption technology in the bioremediation process.

The biosorption process always depends on a number of mechanisms such as complexation, ion exchange, coordination, adsorption, desorption, chelation, and microprecipitation [42, 43]. In general, desorption is one of the most common mechanisms that are employed in the biosorption process [44]. This process is the reverse of sorption (adsorption and absorption). The importance of desorption lies in its potential to actually reuse certain biomass as well as recover sorbents $[16,44]$. Through the use of this biosorptiondesorption process, low-cost heavy metal nanoparticles could be biologically synthesized during the bioremediation process. As far as the literature reviewed for the purposes of this paper, bioabsorption is typically regarded as a passive and metabolically independent process that involves passive biological materials such as biomass [44]. The use of biomass with industrial microbial or agricultural wastes for synthesizing metal nanoparticles contained within wastewater represents an effective, innovative, and sustainable method of waste management.

Bioreduction is very important in both biosorption and bioaccumulation processes. It enhances ion metal biotransformation activity by reducing microorganisms; for example, Chromium (VI) can be reduced to nontoxic Chromium (III) using Shewanella alga, Ochrobactrum, Bacillus, and others [45]. Various researchers have assessed the use of microorganisms to transform Chromium (IV) to Chromium (III) [46-49]. 
Beside living and dead biomass, cell-free extracts are also used as bioreduction agents to produce metal [50]. Cell-free extract is used to give an enzyme and protein molecules capping to the metal salts to reduce them to metal nanoparticles. The cell-free extract from dead biomass produces a higher number of nanoparticles than living cells, dead biomass, and cell-free living cells [51]. The metabolically independent production process yields better morphology of nanoparticles than the metabolism dependent production [52]. This makes it possible to control the size and shape of nanoparticles by adjusting the amount of metal salt and the nonmetabolic bioreduction agents [53] and by controlling the $\mathrm{pH}$ of the aqueous solution [54]. The rate of bioreduction varies according to temperature; the higher the temperature, the higher the rate of bioreduction [55].

Even though the biosorption process is limited, especially in its ability to alter the metal valence state, there are some arguments on the selection of biomass, as reviewed by Nguyen et al. [16]. Beside the availability and cost effectiveness of biomass, selection also depends on the binding capacity of the biomass and selectivity for heavy metals. This will allow the development of a full-scale biosorption process.

Several characterization methods can be used to confirm the presence of metallic nanoparticles. These include transmission electron microscopy (TEM), Fourier transform infrared spectroscopy (FTIR), X-ray diffraction (XRD), energy dispersive X-ray spectroscopy (EDX), field emission scanning electron microscopy (FESEM), energy dispersive $\mathrm{X}$ ray fluorescence spectrometry (EDXRF), and vibrating sample magnetometry (VSM) [56]. The crystallinity of nanoparticles can be investigated by numerous methods such as by $\mathrm{XRD}$, for example, of iron oxide nanoparticles $\left(\mathrm{Fe}_{3} \mathrm{O}_{4} \mathrm{NPs}\right)$ [56] and Silver nanoparticles (AgNPs) [57].

Important features that lead to the production of optimum nanoparticles are their optical properties, surface plasmon resonance (SPR) [58], and effective scattering phenomena [50]. SPR can be characterized by UV-Vis spectroscopy, while surface enhanced Raman scattering can be used to characterize scattering features. A number of groups have presented the ideal characteristics for Gold nanoparticles, where the UV-Vis spectrometer indicates the peak around 450 to $560 \mathrm{~nm}[50,51,59]$.

The biosynthesis process promises a green, safe, cost effective, and sustainable method of producing nanoparticles. The demands for heavy metal industrial activity have led to continuous bioremediation processes, which may lead to the depletion of both microorganisms and dead biomass. In order to reduce costs, it is important that we identify a method of recycling both dead and living microorganisms through the use of immobilization and desorption techniques [12]. The implementation of these techniques has enhanced bioremediation technology through the generation of recycled metal nanoparticles for further application.

The biological approaches used for bioremediation applications are always related to geomicrobiological process [4]. The metal-accumulating mechanisms involved in nanoparticle formation create metal-mineral-microbe interactions.
2.3. Metal Recovery from Heavy Metal Industry Effluent. Metal resources are nonrenewable; as such, the recovery of metal from industrial waste water could provide a means of maintaining the supply of heavy metals [10]. Scientists currently predict that a number of critical metal elements, such as Zinc, Silver, and Gold, will be depleted within the next 50 years if the current rate of consumption is maintained [60]. As a result of the rapid growth of the world economy, the consumption rate of these critical elements is increasing. As discussed in Section 2.1, several conventional remediation methods offer the potential to recover some of these metals from waste products, for example, chemical precipitation, membrane filtration, electrochemical treatment, biobleaching, and adsorption processes.

The use of a bioremediation process that employs a biosorption-desorption mechanism using natural biomass may represent one viable form of environmentally friendly bottom-up nanoparticles synthesis that could help to avoid a metal source depletion crisis $[4,61]$. The definition of biosorption-desorption is discussed in Section 2.3. The quality of the recovered metals or nanoparticles depends on various aspects, such as types of biosorbents, type of metals, ion, $\mathrm{pH}$, and temperature. The synthesis of high quality metal nanoparticles is a field of research that is generally discussed by groups outside bioremediation research. See Sections 2.3 and 2.4 for a comprehensive discussion of nanoparticle biosynthesis.

Various researchers have proposed the use of bioremediation to recover raw materials from waste $[4,61,62]$. In their review of heavy metal removal, Purkayastha et al. [63] compared Cd(II) recovery efficiency between conventional and contemporary methods. The contemporary method of biosorption is widely trusted and is the most popular and frequently used method of heavy metal removal and recovery. It also has the potential to be both a low-cost and environmentally friendly bioremediation process. From [63], a Cd(II) recovery of nearly $100 \%$ efficiency was demonstrated through the use of sulfide precipitation and biosorption processes. The conventional method of sulfide precipitation has the capability to recover $\mathrm{Cd}(\mathrm{II})$ up to $99.9 \%$ from its initial concentration [64]. Similar capability in Cd(II) recovery could also be obtained via a biosorption-leaching method, up to $98.89 \%$ from the initial concentration by using blackgram husk with $0.1 \mathrm{M} \mathrm{HCl}$ as a leaching agent [65]; the use of sawdusk obtained from mulberry wood with $1.5 \mathrm{M} \mathrm{HCl}$ has achieved Cd(II) recovery capability up to $92.79 \%$ [66], while Cd(II) recovery of up to $98.7 \%$ was obtained by using an Annona squamosa-based absorbent with $0.1 \mathrm{M} \mathrm{HCl}$ [67]. A $\mathrm{Cd}$ (II) recovery of up to $82 \%$ was obtained by using the biomass of Pseudomonas aeruginosa with $0.1 \mathrm{M} \mathrm{HCl}$ [68]. The recovery of $\mathrm{Cu}(\mathrm{II})$ of $100 \%$ was obtained by using volcanic rock matrix-immobilized Pseudomonas putida cells with surface-displayed cyanobacterial metallothioneins at $\mathrm{pH} 2.35$ [69]. $100 \%$ recovery of $\mathrm{Cu}(\mathrm{II})$ was also obtained by using the activated sludge at $\mathrm{pH} 1$ [70]. Over $90 \%$ recovery of $\mathrm{Cu}$ and $\mathrm{Pb}$ was obtained at $\mathrm{pH} \leq 2$ through the use of an indigenous isolate Enterobacter sp.J1 [71]. Liu et al. [72] compared the recovery efficiency between biosorption-leaching and biosorption-pyrolysis technology when recovering $\mathrm{Pb}$ from 
an aqueous solution. $\mathrm{A} \mathrm{Pb}$ recovery of up to $94.9 \%$ was achieved in $\mathrm{HCl}$ solution, while $98.2 \%$ was achieved via the fast pyrolysis process.

Heavy metals can also be removed and recovered through bioleaching, which utilizes microorganisms as reduction agents [62]. The efficiency of the recovery process depends on the ability of the microorganisms to transform the solid compound within the contaminated soil into a soluble substance that can be extracted and recovered.

Several methods can be applied to achieve physical synthesis of metallic nanoparticles. These include attrition and pyrolysis. However, the process involves a significant conversion of energy to maintain the high pressure and temperature required during the synthesis process [73]. Topdown synthesis in the physical approach involves methods such as thermal decomposition, diffusion, irradiation, and arc discharge.

Chemical procedures are generally low-cost and can process high volumes; however, they typically involve the use of toxic solvents and generate hazardous byproducts. Examples of a bottom-up synthesis using a chemical approach include the seeded growth method, the polyol synthesis method, electrochemical synthesis, and chemical reduction. Scientists have successfully used a chemical reduction method to reduce a metal particle to nanoparticles using chemical agents such as Sodium borohydride or Sodium citrate.

Biological methods in the synthesis of metallic nanoparticles are becoming increasingly popular as they are lowcost, nontoxic, and environmentally benign. Synthesis using biological methods, especially those involving plants, can actively reduce metal ions in a biocompatible way where they can secrete functional biomolecules. The biological agents that are used in the biological approach to the synthesis of nanoparticles involve a variety of microbes $[58,74]$ including bacteria [73], fungi $[75,76]$, yeast, and plants [77].

\subsection{Biosynthesis as an Approach to Producing Nanoparticles} during a Bioremediation Process. Various review papers deal with the relationship between the bioremediation process and the production of metal nanoparticles $[4,61]$. The main process that is used for both bioremediation and biosynthesis of nanoparticles is biosorption $[8,11]$. Nanoparticle biosynthesis can be mediated by the biomass of plants and microorganisms (bacteria, algae, fungi, and yeast) through biosorption.

Biosynthesis is a bottom-up approach that uses biological molecular size entities to form nanoparticles [78]. Various biosynthetic methods are used to produce stable metal nanoparticles [79]. The biosynthesis of Gold, Silver, GoldSilver, Platinum, Palladium, silica, alloy, Titanium, zirconia, Selenium, and Tellurium nanoparticles has already been reported [58]. Organisms, both unicellular and multicellular, have demonstrated unique potential in the environmentally friendly production and the accumulation of nanoparticles of different shapes and sizes that can be utilized for different commercial applications. Biosynthesis approaches for the production of metallic nanoparticles were reviewed by various groups [79]. Kulkarni and Muddapur [56] published a review on single-step biosynthesis mechanism of metal and metal oxide nanoparticles through the use of plants and microorganisms. The biomolecules present in plant extracts can be used to reduce metal or metal oxide ions to nanoparticles. This approach is low-cost, nontoxic, and environmentally benign and it allows the size of the nanoparticles to be controlled. The methods of nanoparticle characterization are used to understand the mechanism of particle formation and determine its future application [79]. In the biosynthesis of nanoparticles, different major factors, such as $\mathrm{pH}$, temperature, concentration of metal ions, and concentration of extracts, influence the process of reducing metal ions to metal nanoparticles $[57,80]$.

2.4.1. Plant-Mediated Biosynthesis of Nanoparticles. Plants have demonstrated a better ability to mediate nanoparticle synthesis than other methods and they offer a number of further advantages [78]. During the biosynthesis process, plants as biological agents act as reducing and capping agents [57]. Every part of the plant can be used for nanoparticles including leaves, flower, seeds, stems, fruits, latex, and calli. Furthermore, biomass from dead and dried plants can also be used for the synthesis of nanoparticles [81].

Research in plant-mediated biosynthesis of nanoparticles that has been conducted over the past 10 years (20032012) was reviewed extensively by Mittal et al. [74]. Over 50 different types of plant extracts have been used to synthesize metal nanoparticles and these have mostly been employed to produce Silver and Gold nanoparticles and alloys of different sizes and shapes [74]. A review of Iron, Zinc oxide, Selenium, Silver, and Gold nanoparticles that were mediated by plants, marine plants, and some microorganisms was published by Kulkarni and Muddappur [56]. Table 2 displays the results of a recent project which was not reviewed by Mittal et al. [74] and Kulkarni and Muddappur [56] in their review papers.

Of the reviewed projects (which were all conducted in the last 10 years before 2014), the majority of the plant extracts employed were derived from the leaf part of the plant. In order to create a sustainable method of recycling metal industrial effluent through the use of bioremediation technology, green and low-cost bioreduction agents from food industrial waste biomass should be used. Fruit peel, tea leaves, seeds, and flowers are among large-scale food industrial waste products and agricultural waste that should be reused to obtain a sustainable resource that can have a nanotechnology application.

The development of Gold and Silver nanoparticles is highly attractive to researchers due to the nobility of these metals and their wide range of applications, especially in biomedical and biochemistry fields. Remediating the waste produced by the Gold and Silver mining industry and its leachates through the use of food industrial waste not only will clean the water or soil of metal waste, but also could reduce the cost of the process.

\subsubsection{Microorganism-Mediated Biosynthesis of Nanoparticles}

(1) Bacteria-Mediated Biosynthesis of Nanoparticles. The strong relationship between bioremediation technologies and the bacteria-mediated biosynthesis of nanoparticles through the application of biosorption was discussed by 
TABLE 2: Plant extract-based biosynthesis of metal or metal-based ion nanoparticles.

\begin{tabular}{|c|c|c|c|c|}
\hline Plant/plant part extract & Scientific name & Metal NPs & NPs size $(\mathrm{nm})$ & Reference \\
\hline Leaf & Lemon & $\mathrm{Se}$ & $60-80$ & {$[82]$} \\
\hline Leaf & Green tea & Fe ion & & {$[83]$} \\
\hline Leaf & Ecliptaprostrata & $\mathrm{TiO}$ & $36-68$ & {$[84]$} \\
\hline Leaf & Cinnamomum tamala & $\mathrm{Au} / \mathrm{TiO}_{2}$ & $8-20$ & {$[85]$} \\
\hline Plant & Cacumen platycladi & $\mathrm{Pt}$ & $2.4 \pm 0.8$ & {$[86]$} \\
\hline Leaf & Ocimum tenuiflorum (Tulasi) & $\mathrm{Ag}$ & $7-15$ & {$[87]$} \\
\hline Leaf & Chenopodium murale & $\mathrm{Ag}$ & $30-50$ & {$[88]$} \\
\hline Gum olibanum & Boswellia serrata & $\mathrm{Ag}$ & $7.5 \pm 3.8$ & [89] \\
\hline Leaf & Cissus quadrangularis Linn & $\mathrm{Ag}$ & $15-23$ & {$[90]$} \\
\hline Leaf & Aloe & $\mathrm{Ag}$ & 20 & {$[91]$} \\
\hline Fruit & Tribulus terrestris & $\mathrm{Ag}$ & $16-28$ & {$[92]$} \\
\hline Leaves & Stevia rebaudiana & Ag & $2-50$ & {$[93]$} \\
\hline Leaf & Artemisia nilagirica & $\mathrm{Ag}$ & $70-90$ & {$[94]$} \\
\hline Root & Morinda citrifolia & $\mathrm{Ag}$ & $30-55$ & {$[95]$} \\
\hline Leave & Rhizophora apiculata & $\mathrm{Ag}$ & $19-42$ & [96] \\
\hline Leaf & Prosopis juliflora & $\mathrm{Ag}$ & $35-60$ & [97] \\
\hline Leaf & Olive & $\mathrm{Ag}$ & $20-25$ & {$[98]$} \\
\hline Fruit & Terminalia chebula & $\mathrm{Ag}$ & 25 & {$[99]$} \\
\hline Coir & Cocos nucifera & $\mathrm{Ag}$ & $23 \pm 2$ & {$[100]$} \\
\hline Leaf & Malva parviflora & $\mathrm{Ag}$ & $19-25$ & {$[101]$} \\
\hline Leaf & Mangifera indica & $\mathrm{Ag}$ & 20 & {$[102]$} \\
\hline Peel & Mangifera indica Linn (Mango) & $\mathrm{Ag}$ & $7-77$ & {$[103]$} \\
\hline Leaf & Origanum vulgare & $\mathrm{Ag}$ & $136 \pm 10.09$ & {$[104]$} \\
\hline Leaf & Pepper & $\mathrm{Ag}$ & 5-60 & {$[105]$} \\
\hline Leaf & Coccinia grandis & $\mathrm{Ag}$ & $20-30$ & {$[106]$} \\
\hline Leaf & Catharanthus roseus Linn G. Donn & $\mathrm{Ag}$ & $27-32$ & {$[107]$} \\
\hline Peel & Citrus unshiu & $\mathrm{Ag}$ & $5-20$ & {$[108]$} \\
\hline Plant & Scutellaria barbata D. Don & $\mathrm{Au}$ & $5-30$ & {$[59]$} \\
\hline Seed & Benincasa hispida & $\mathrm{Au}$ & $10-30$ & {$[55]$} \\
\hline Pod & Gymnocladus assamicus & $\mathrm{Au}$ & $4.57 \pm 0.23-22.57 \pm 1.24$ & {$[109]$} \\
\hline Leaf & Piper betle & $\mathrm{Au}$ & $50($ mean size $)$ & {$[110]$} \\
\hline Pulp & Beta vulgaris & $\mathrm{Au}$ & $\begin{array}{l}\text { Nanorod }(25 \mathrm{~nm}) \\
\text { Nanowire }(30 \mathrm{~nm})\end{array}$ & {$[111]$} \\
\hline Leaf, stem, root & Ipomoea carnea & $\mathrm{Au}$ & $3-100$ & [112] \\
\hline Marine plant & Sargassum muticum & $\mathrm{Au}$ & & [113] \\
\hline Glucan of mushroom & Pleurotus florida & $\mathrm{Au}$ & $5.33-18$ & {$[114]$} \\
\hline \multirow{2}{*}{ Plant } & Zingiber officinale & $\mathrm{Au}$ & 5-15 & {$[115]$} \\
\hline & Crocus sativus & $\mathrm{Au}$ & $11-20$ & {$[116]$} \\
\hline Leaf & Hibiscus rosasinensis & $\mathrm{Au}$ & & {$[117]$} \\
\hline Leaf & Green tea & $\mathrm{Au}$ & 20 & {$[118]$} \\
\hline Flower & Rosa damascena & $\mathrm{Au}, \mathrm{Ag}$ & $10-30$ & {$[119]$} \\
\hline
\end{tabular}

various researchers [120, 121]. Kulkarni and Muddappur [56] reviewed recent research on the biosynthesis of metal nanoparticles through the use of bacteria as reduction agents. Table 3 lists the types of bacteria that synthesize metal nanoparticles. Most such syntheses are extracellular binding metal nanoparticles to bacterial biomass. The bacterial biomass, such as Pseudomonas aeruginosa and Aeromonas hydrophila, is obtained at low cost from waste from bacterial synthesis in the plastic industry, polyhydroxyalkanoates [122]. Due to the biodegradability of these materials, polyhydroxyalkanoates are desirable and will offer continuous production on a large scale [123]. Thus, the production of both $P$. aeruginosa and $A$. hydrophila biomass will continuously be available and offer access to low-cost Gold and Zinc 
TABLE 3: Bacteria-mediated biosynthesis of nanoparticles.

\begin{tabular}{|c|c|c|c|}
\hline Metal/metal oxide & Microorganisms & & $\begin{array}{c}\text { Nanoparticle } \\
\text { size }(\mathrm{nm})\end{array}$ \\
\hline \multirow{8}{*}{$\mathrm{Au}$} & Geobacillus sp. [125] & & $5-50$ \\
\hline & Klebsiella pneumoneae [126] & & \\
\hline & Escherichia coli $[127,128]$ & Extracellular & $\begin{array}{c}17-32,5-70 \\
\text { (uniform at 2.2) }\end{array}$ \\
\hline & Magnetospirillum gryphiswaldense MSR-1 [54] & Extracellular & $10-40$ \\
\hline & Pseudomonas aeruginosa $[129]$ & Extracellular & $15-30$ \\
\hline & Rhodopseudomonas capsulate [130] & Extracellular & $10-20$ \\
\hline & Micrococcus luteus [131] & Extracellular & $6 \mathrm{~nm}$ and $50 \mathrm{~nm}$ \\
\hline & Stenotrophomonas [132] & $\begin{array}{l}\text { Extracellular marine } \\
\text { source }\end{array}$ & $10-50$ \\
\hline \multirow{9}{*}{$\mathrm{Ag}$} & E.coli $[133]$ & & \\
\hline & Lactobacillus sp. [134] & & $10-25$ \\
\hline & Bacillus licheniformis [135] & & $2-100$ \\
\hline & Streptomyces hygroscopicus (BDUS 49) [136] & Live cells from sewage & $20-30$ \\
\hline & Corynebacterium glutamicum (0) [120] & & $5-50$ \\
\hline & Streptomyces sp. BDUKAS10 [137] & Extracellular & $21-48$ \\
\hline & Bacillus cereus $[138]$ & & $4-5$ \\
\hline & Bacillus amyloliquefaciens LSSE-62 [139] & Intracellular & 14.6 \\
\hline & Stenotrophomonas [132] & & $40-60$ \\
\hline \multirow{3}{*}{$\mathrm{Se}$} & Klebsiella pneumoneae $[9,133]$ & & $100-550$ \\
\hline & Zooglea ramigera $[140]$ & Extracellular & $30-150$ \\
\hline & Bacillus subtilis [141] & Extracellular & $50-400$ \\
\hline $\mathrm{Ag}_{2} \mathrm{O}$ & Lactobacillus mindensis [142] & & $2-20$ \\
\hline $\mathrm{Ti}$ & Lactobacillus sp. [134] & & $10-70$ \\
\hline $\mathrm{TiO}_{2}$ & Bacillus subtilis [143] & & $66-77,10-30$ \\
\hline \multirow{2}{*}{$\mathrm{Cu}_{2} \mathrm{~S}$} & Streptomyces sp. [144] & & $100-150$ \\
\hline & Desulfovibrio desulfuricans [121] & & $20-30$ \\
\hline Zinc nitrate & Streptomyces sp. [144] & & $100-150$ \\
\hline \multirow{4}{*}{$\mathrm{ZnO}$} & Calotropis gigantean [145] & & \\
\hline & Lactobacillus sporogenes [146] & & $5-15$ \\
\hline & Lactobacillus plantarum VITES07 [147] & & $7-19$ \\
\hline & Aeromonas hydrophila [148] & & 57.72 \\
\hline $\mathrm{CdS}$ & Rhodopseudomonas [149] & Intracellular & $8.01 \pm 0.25$ \\
\hline
\end{tabular}

oxide nanoparticle biosynthesis, respectively, especially with intention to recover these metals from the industrial effluent produced by the metals industry. The Selenium and Titanium oxide nanoparticle biosynthesis could also be continuously obtained, since Bacillus subtilis biomass is available on a continuous basis. Bacillus subtilis-based enzymes are in high demand in a number of consumer chemical production industries such as those that produce cleaning products, paper and textiles, food, and pesticides [124].

Many other forms of bacteria biomass could be obtained from industrial waste and subsequently be used for the lowcost, environmentally friendly, and sustainable bioremediation of metal industrial effluents.

(2) Fungi-Mediated Biosynthesis of Nanoparticles. The fungimediated biosynthesis of Silver nanoparticles was reported by
Duran et al. [79]. Uniformity in terms of size and shape of the Gold nanoparticles formed through the use of Aspergillus oryzae var. viridis (waste industrial fungal biomass from industry) ranged between 10 and $60 \mathrm{~nm}$ [51]. Mishra et al. [52] reported the potential of an industrially important fungus, Penicillium rugulosum, for the synthesis of Gold nanoparticles. Reduction of Silver nitrate to Silver metallic nanoparticles is currently an established routine in laboratories worldwide. Vigneshwaran et al. [150] investigated the use of white rot fungus Phaenerochaete chrysosporium for the extracellular synthesis of Silver nanoparticles. The mycelium of $P$. chrysosporium was found to reduce Silver nitrate to metallic silver nanoparticles. Utilization of Coriolus versicolor to reduce Silver nitrate to Silver metallic nanoparticles was reported by Sanghi and Verma [151]. The formation of Silver nanoparticles through an extracellular cell wall reduction 
TABle 4: Fungi-mediated biosynthesis of metal nanoparticles.

\begin{tabular}{|c|c|c|c|}
\hline NPs & Name & Binding location & Size of NPs (nm) \\
\hline $\mathrm{Ag}$ & Phaenerochaete chrysosporium [150] & Extracellular & $50-200$ \\
\hline $\mathrm{Ag}$ & Aspergillus flavus [152] & Extracellular & $8.92 \pm 1.61$ \\
\hline $\mathrm{Ag}$ & Coriolus versicolor $[151]$ & Intra-/extracellular & \\
\hline $\mathrm{Ag}$ & Penicillium brevicompactum WA2315 [154] & Extracellular & 23-105 \\
\hline $\mathrm{Ag}$ & Cladosporium cladosporioides [155] & Extracellular & $10-100$ \\
\hline $\mathrm{Ag}$ & Candida albicans [50] & & $5-30$ \\
\hline $\mathrm{Ag}$ & Neurospora crassa $[156]$ & Intra-/extracellular & 11 \\
\hline $\mathrm{Ag}$ & Fusarium oxysporum [157] & Extracellular & $5-15$ \\
\hline $\mathrm{Pt}$ & Fusarium oxysporum [158] & Extracellular & $5-30$ \\
\hline $\mathrm{TiO}_{2}$ & Aspergillus flavus [159] & Extracellular & $62-74$ \\
\hline $\mathrm{TiO}_{2}$ & Humicola sp.[160] & & \\
\hline $\mathrm{ZnO}$ & Candida albicans [161] & & \\
\hline $\mathrm{Au}$ & Aspergillus oryzae var.viridis [51] & & $30-400$ \\
\hline $\mathrm{Au}$ & Sclerotium rolfsii $[53]$ & & 25 \\
\hline $\mathrm{Au}$ & Penicillium rugulosum[52] & & $20-80$ \\
\hline $\mathrm{Au}$ & Cylindrocladinum [162] & & $5-35$ \\
\hline $\mathrm{Au}$ & Candida albicans [50] & & $5-30$ \\
\hline $\mathrm{Au}$ & Neurospora crassa [156] & Intra-/extracellular & 32 \\
\hline
\end{tabular}

process of Silver nitrate by using Aspergillus flavus was successfully performed by Vigneshwaran et al. [152]. Silver nanoparticles with a size of $8.92 \pm 1.61 \mathrm{~nm}$ were obtained in this study. Silver metallic nanoparticles that were $5-25 \mathrm{~nm}$ in size were obtained through extracellular biosynthesis by using Aspergillus fumigatus [153]. Table 4 shows the fungimediated biosynthesis of metals nanoparticles for noble metals.

(3) Algae-Mediated Biosynthesis of Nanoparticles. Abdel-Aziz et al. [88] successfully obtained Gold nanoparticles that were $3.85-77.13 \mathrm{~nm}$ in size through the use of an extract of the Galaxaura elongata algae. The use of $G$. elongata to obtain the nanosize Gold nanoparticles demonstrated the high effectiveness of this method compared to the use of E. coli and K. pneumonia, which yielded Gold nanoparticles of size 13.5 and $13 \mathrm{~nm}$, respectively. Arockiya et al. [163] obtained Gold nanoparticles of a size ranging between 18.7 and $93.7 \mathrm{~nm}$ through the use of Stoechospermum marginatum. The obtained nanoparticles demonstrated potential to be used as antibacterial agents.

(4) Yeast-Mediated Biosynthesis of Nanoparticles. Au nanoparticles have been obtained through the use of the Saccharomyces cerevisiae AP22 yeast and CCFY-100 through accumulation processes inside the cells [164], while Ag nanoparticles with an average size of $19 \pm 9 \mathrm{~nm}$ were obtained through the use of the Saccharomyces cerevisiae BU-MBTCY1 yeast [165].

2.5. Hyperaccumulation of Metals for Phytomining Applications. Accumulation of metal by plant species for soil remediation was first used as early as 1983, and it advanced to an accepted metal mining technology in recent years [34]. Metal accumulating species can be used for phytoremediation (removal of contaminants from soils) (as discussed in Section 2.4) or for phytomining, which involves growing plants to harvest metals (this will be discussed in this section). In addition, many of the metals that can be hyperaccumulated also provide essential nutrients; food fortification and phytoremediation might be considered two sides of the same coin [166]. Many heavy metals are essential or beneficial as micronutrients for the growth and metabolism of microorganisms, plants, and animals but are dangerous if found in high concentrations. These include Cobalt (Co), Copper $(\mathrm{Cu})$, Iron ( $\mathrm{Fe})$, Manganese (Mn), Molybdenum (Mo), Nickel $(\mathrm{Ni})$, and Zinc $(\mathrm{Zn})$. On the other hand, some heavy metals do not seem to be essential because there is no demonstrated biological or physiological function (yet). These include Lead $(\mathrm{Pb})$, Arsenic (As), Cadmium $(\mathrm{Cd})$, and Mercury $(\mathrm{Hg})$. Several reasons and hypotheses exist concerning why some plants hyperaccumulate metals. The first is that the metals [166] provide the plants with a physiological strategy that protects them from herbivore attack through feeding deterrence and from pathogen attack through their toxicity [34, 166]. Sagner and coworkers [167] observed the repellent effect that plant sap had on the fruit fly Drosophila melanogaster, indicating that, in hyperaccumulating plants, Nickel serves as an agent to prevent predation. Furthermore, the defensive enhancement increases with increasing metal concentration [168]. Hyperaccumulator species are distributed across a wide range of distantly related families, showing that the hyperaccumulation trait has evolved independently more than once under the spur of selective ecological factors. The ability of plant species to accumulate heavy metals is of interest in multidisciplinary fields as it holds potential for the development of technologies that are of human and environmental concern.

2.5.1. Hyperaccumulation of Metal by Plants. Plants have the ability to accumulate metals from the soil in their tissue 
during growth and development. The hyperaccumulation process offers a new, environmentally friendly method of producing metal nanoparticles [34]. The term "hyperaccumulator" describes plants that have the ability to grow on metalliferous soils and to accumulate extraordinarily high amounts of heavy metals that are far in excess of the levels found in the majority of species in their aerial organs, without suffering phytotoxic effects [169]. Chaney [170] proposed the idea of using plants that hyperaccumulate metals to selectively remove and recycle excessive metals in soil. Hyperaccumulator plants have been defined as those that accumulate metal in concentrations that are 10-100 times more than those found in normal plants [170]. According to Reeves [171], there are 440 hyperaccumulator plant species, of which $75 \%$ are Nickel hyperaccumulators. Other plant species accumulate metals like Cadmium, Arsenic, Manganese, Sodium, Thallium, and Zinc. When metal ions have been taken up and are concentrated in the tissue of the hyperaccumulator plants, the biomass may be harvested, dried, and burnt to ash for recycling as a bio-ore $[172,173]$ or stored for later use.

Wei and coworkers [174] summarized the main characteristics of hyperaccumulator plants as follows:

(i) accumulation property, that is, the minimum concentration in the shoots of a hyperaccumulator; for As, $\mathrm{Pb}, \mathrm{Cu}, \mathrm{Ni}$, and $\mathrm{Co}$, it should be greater than $1000 \mathrm{mg}$ $\mathrm{kg}^{-1}$ dry mass, for $\mathrm{Zn}$ and $\mathrm{Mn} 10,000 \mathrm{mg} \mathrm{kg}^{-1}$, for $\mathrm{Au}$ $1 \mathrm{mg} \mathrm{kg}^{-1}$ and Cd $100 \mathrm{mg} \mathrm{kg}^{-1}$, respectively [175];

(ii) translocation property; that is, elemental concentrations in the shoots of a plant should be higher than those in the roots [176, 177];

(iii) enrichment property; that is, enrichment factor EF (concentration ratio of plant to media) in shoots of plants should be higher than those in roots [178];

(iv) tolerance property; that is, a hyperaccumulator should have high tolerance to heavy metals [178]. The tolerance mechanism in plants that hyperaccumulate Cd was explored from root morphology by Wei and coworkers [174].

Hyperaccumulation by plants includes the uptake of heavy metal through "root-to-shoot." The majority of the heavy metal is absorbed from the soil by the root and then detoxified by chelation in the cytoplasm or stored in vacuoles. Hyperaccumulators rapidly and efficiently translocate the element to the shoot via the xylem. Rascio and NavariIzzo [166] described three basic characteristics by which hyperaccumulator plants can be distinguished from nonaccumulation plant species:

(1) a much greater capability to extract heavy metals from the soils,

(2) a faster and effective root-to-shoot translocation of metals, and

(3) a much greater ability to detoxify and sequester huge amounts of heavy metals in the leaves.
Plants Species in Hyperaccumulation. Many species of plant can hyperaccumulate heavy metals. These include Asteraceae, Brassicaceae, Caryophyllaceae, Cyperaceae, Cunouniaceae, Fabaceae, Flacourtiaceae, Lamiaceae, Poaceae, Violaceae, Sapotaceae, and Euphobiaceae. The Brassicaceae family has the largest number of taxa, consisting of about 11 genera and 87 species. Members of the family Bracecaceaeaare are well known as hyperaccumulators of Nickel (genera Thalaspi and Alyssum), Cadmium, and Zinc (Thalaspi caerulescens, T. praecox, T. geosingese, and Arabidopsis halleri). According to research performed by Sagner et al. [167] and Jaffre et al. [179], the highest concentration of Nickel in latex has been recorded in different parts (latex, leaves, trunk bark, twig bark, fruits, and wood) of the Sebertia acuminata (Sapotaceae) tree from New Caledonia. More taxa of plants species are accumulators of Nickel (more than 75\%) than of any other metal, and only five species accumulate Cadmium [166]. Several heavy metal hyperaccumulating species that belong to the Thlaspi genus have been studied, among them Thlaspi caerulescens hyperaccumulating $\mathrm{Zn} / \mathrm{Cd}$ [180], Thlaspi rotundifolium ssp. cepaeifolium hyperaccumulating $\mathrm{Pb}$ [173], and T. praecox Wulf hyperaccumulating Zn [181]. The hyperaccumulator plant Alyssum murale can accumulate Ni up to $20,000 \mathrm{mg} \mathrm{kg}^{-1} \mathrm{dry}$ weight, and a biomass of $10,000 \mathrm{~kg} / \mathrm{ha}$ can be harvested per year [182]. Serpentine soils contain $\mathrm{Ni}$ at concentrations between 1000 and $7000 \mathrm{mg} \mathrm{kg}^{-1}$. These concentrations are well below the exploitation threshold required by traditional mining $\left(30,000 \mathrm{mg} \mathrm{kg}^{-1}\right)$ but are sufficient to allow hyperaccumulating plants to extract and accumulate $\mathrm{Ni}$ [175]. A selection of hyperaccumulator plant species and their threshold concentrations is given in Table 5 .

Lin and coworkers [190] examined the different concentrations of Copper sulphate in the growth and accumulation of $\mathrm{Cu}^{2+}$ in different parts, such as in the root, hypocotyl, cotyledon, and leaf, of the sunflower (Helianthus annuus L.) plant. They found that the concentration of $\mathrm{Cu}^{2+}$ was higher in the roots than it was in other parts of the Helianthus annuus and concluded that these plants have the potential ability to accumulate Copper. Copper is a catalytic cofactor of enzymes and is necessary in the normal growth and development of many plants species. Juárez-Santillán and coworkers [197] carried out an experiment that aimed to identify Manganese accumulation in the plants growing in the mining zone of Hidalgo, Mexico. They used eight species of accumulator plants and found a Mn content in the substrate ranging from 11,637 to $106,104 \mathrm{mg} \mathrm{kg}^{-1}$ dry weight, with the concentrations being between 2 and 21 times higher than the phototoxic level of 5,000 mg kg-1 dry weight according to Alloway [198]. Jiang and coworkers [191] investigated the effects of Cadmium chloride concentration, uptake, and accumulation of $\mathrm{Cd}^{2+}$ using the hyperaccumulator garlic Allium sativum $\mathrm{L}$. Their results showed that the concentration of Cadmium was higher in the roots than it was in the shoot and bulb.

Types of Hyperaccumulation. There are two types of hyperaccumulation, natural (using plants) and induced (adding chemicals). Natural hyperaccumulation occurs when plant species use their physiological ability to accumulate the state 
TABLE 5: Hyperaccumulators in phytomining. Source: van der Ent et al. [183] with modifications, together with the metal concentration in selected hyperaccumulators.

\begin{tabular}{|c|c|c|c|c|}
\hline Metal & $\begin{array}{c}\text { Number of } \\
\text { hyperaccumulator } \\
\text { species recorded }\end{array}$ & $\begin{array}{l}\text { Hyperaccumulation } \\
\text { threshold }\left(\mathrm{mg} \mathrm{kg}^{-1}\right)\end{array}$ & Selected hyperaccumulator species & $\begin{array}{l}\text { Concentration of } \\
\text { metals (mg/kg d.w.) }\end{array}$ \\
\hline \multirow{7}{*}{ Nickel } & \multirow{7}{*}{450} & \multirow{7}{*}{1000} & Sebertia acuminate $[167,179]$ & \\
\hline & & & Streptanthus polygaloides $[184,185]$ & \\
\hline & & & Alyssum bertolonii $[186,187]$ & 13400 \\
\hline & & & Berkheya coddii [187] & 17000 \\
\hline & & & Thlaspi geosingense [188] & \\
\hline & & & Alyssum tenium [19] & \\
\hline & & & Alyssum troodii $[19]$ & \\
\hline Cobalt & 30 & 300 & Haumaniastrum robertii [189] & 10200 \\
\hline \multirow{2}{*}{ Copper } & \multirow{2}{*}{32} & \multirow{2}{*}{300} & Helianthus annuus L. [190] & \\
\hline & & & Haumaniastrum katangense [169] & 8356 \\
\hline \multirow[t]{2}{*}{ Zinc } & \multirow[t]{2}{*}{12} & \multirow[t]{2}{*}{3000} & Thlaspi calaminare [181] & 10000 \\
\hline & & & Thlaspi caerulescens & \\
\hline \multirow[t]{2}{*}{ Zinc and Cadmium } & \multirow{6}{*}{2} & \multirow{6}{*}{100} & Sedum alfredii & \\
\hline & & & Polycarpaea longiflora [19] & \\
\hline \multirow{4}{*}{ Cadmium } & & & Allium sativum L. [191] & \\
\hline & & & Thlaspi caerulescens [19] & 3000 \\
\hline & & & Solanum nigrum [192] & \\
\hline & & & Rorippa globosa [174] & \\
\hline $\begin{array}{l}\text { Gold (induced } \\
\text { hyperaccumulation) }\end{array}$ & & 1 & $\begin{array}{l}\text { Brassica juncea } \\
\text { Barkley coddii }[193,194]\end{array}$ & 10 \\
\hline Manganese & 12 & 10000 & Macadamia neurophylla [195] & 55000 \\
\hline Lead & 14 & 1000 & Thlaspi rotundifolium subsp. [181] & 8200 \\
\hline Thallium & 2 & 100 & $\begin{array}{l}\text { Biscutella laevigata } \\
\text { Iberis intermedia }[193,196]\end{array}$ & 4055 \\
\hline
\end{tabular}

of heavy metals as a normal function of their growth, while induced hyperaccumulation is performed by adding chemicals to the soil in order to manipulate the soil-plant environment. Several pieces of research have covered hyperaccumulation [34]. The majority of the discussion in the existing reports concentrates on natural hyperaccumulation. Anderson and coworkers [193] attempted to induce plants to hyperaccumulate $\mathrm{Au}$ by adding ammonium thiocyanate to substrate, and their results revealed that Indian mustard (Brassica juncea) accumulated up to $57 \mathrm{mg} \mathrm{kg}^{-1}$. In this research, the hyperaccumulation of Gold was defined as accumulation greater than $1 \mathrm{mg} \mathrm{kg}^{-1}$ based on normal concentration in plants of $0.01 \mathrm{mg} \mathrm{kg}^{-1}[199,200]$.

2.5.2. Hyperaccumulation of Metal by Others. Aquatic macrophytes, such as Eleocharis acicularis, hold great potential for phytoremediation of water contaminated with multiple heavy metals from mine tailings, mine drainage, and water [201, 202]. Ha and coworkers [203] completed a laboratory investigation in which they studied the ability of dwarf hair grass (Eleocharis acicularis) to accumulate Indium, Silver, Copper, Cadmium, Lead, and Zinc and assessed phytoremediation and phytomining. Their results indicated that Eleocharis acicularis does have the ability to accumulate metals; the concentrations of metals in the roots of the plant were as follows: Indium $477 \mathrm{mg} \mathrm{kg}^{-1}$, Silver $326 \mathrm{mg} \mathrm{kg}^{-1}$, Copper $575 \mathrm{mg} \mathrm{kg}^{-1}$, Cadmium $195 \mathrm{mg} \mathrm{kg}^{-1}$, Lead $1120 \mathrm{mg} \mathrm{kg}^{-1}$, and Zinc $213 \mathrm{mg} \mathrm{kg}^{-1}$ dry weight after 15 days exposure, and they concluded that there was the potential to extract Indium and Silver from these plants and that they can be used for phytomining.

2.5.3. How Organisms Accumulate Heavy Metals. As discussed above, bioaccumulation involves the accumulation of metal from the soil or water and is always performed by living microorganisms such as bacteria, fungi, algae, and yeast $[8,10]$. The microorganisms take up the metal into the cell across the cell membrane [11]. Understanding the mechanism of biosorption and the structure of the cell wall or cell membrane is important to identify an appropriate method of removing metals from polluted water or soil. Microbes, including eukaryotes and prokaryotes, interact with metals and minerals in natural and symbiotic association with each other and other organisms. They can alter the physical and chemical condition and have an impact on the growth, activity, and survival of microbials [4]. Chmielewská and Medved [204] confirmed the high $\mathrm{Ni}^{2+}$ bioaccumulation ability of Cladophora glomerata. Furthermore, Microspora 
also might have potential to be useful in bioremediation. The mechanisms by which metal is bound to microbial biomass are divided into three types:

(i) intracellular accumulation, where the process requires live cells,

(ii) sorption or complex formation on the cell surface for both living and dead cells, and

(iii) extracellular accumulation or precipitation where the process may require viable cells $[205,206]$.

Bioaccumulation via growing cells is a potential technique for removing heavy metals from a food environment. The heavy metals can be both biosorbed onto the cell surface and passed into the cell across the cell membrane through the cell metabolic cycle [207].

The uptake of metal ions by living and dead cells consists of two methods; either the metal ions bind to the surface of the cell wall and extracellular material or the metal is absorbed into the cell across the cell membrane, which is referred to as intracellular uptake, active uptake, or bioaccumulation [5]. The first method occurs in both living and dead cells in biomass, while the second method, which is dependent on the plants' metabolism, occurs only in living cells. As such, both living and dead cells are capable of metal adsorption [208]. The use of dead biomass is preferred to living matter due to the absence of toxicity limitations, growth media and nutrient requirements, and the high capacity of the binding metals. Metal uptake is also facilitated by the production of metal-binding proteins in living cells.

A less energy dependent approach for bioaccumulating Gold nanoparticles was successfully performed through the use of two different strains of yeast, Saccharomyces cerevisiae AP22 and CCFY-100 [164]. The ion Gold (III) is reduced to Gold (0) and the nanoparticles accumulate inside the cell nucleolus. Narayanan and Sakthivel [162] successfully synthesized nano-Gold composite by using the fungus Cylindrocladium floridanum via an intracellular accumulation process. This study introduced the use of microbially matrixed Gold nanoparticles as heterogeneous catalysts to control the accumulation of the nano-Gold composite.

2.5.4. Phytomining of Various Metals. Phytomining has emerged as an environmentally friendly technology that uses plants to extract heavy metals from a given substance [173, 193]. This technology involves growing and harvesting metalaccumulating plants on appropriate sites and treating the biomass to recover the metal. Phytomining describes the bioharvesting of metals from high biomass crops grown in soil substrates, particularly those associated with subeconomic mineralization. Phytomining involves growing high-biomass plants that accumulate high metal concentrations. Phytomining technology is perhaps the most feasible, lowcost, and environmentally friendly alternative to conventional mining methods as it allows the economic exploitation of mineralized soils that are thought too metal-poor for direct mining operations. The technique of phytomining involves growing a crop of a metal-hyperaccumulating plant species, harvesting the biomass, and burning it to produce a bioore [193]. Pythomining has been suggested as a potential alternative to recovering metal for other applications. In this situation, several studies have attempted to recover metals, such as Nickel [189, 209, 210], from mineralized soils or waste rock. Phytomining employs hyperaccumulating plants to extract valuable metals from the substrate. Many metals, such as Nickel, Cadmium, and Manganese, occur naturally in hyperaccumulator plant species because most metals are bioavailable in the soil solution in which the plants grow [175].

Phytomining offers the possibility to exploit metals derived from low-grade ore, overburdens, mill tailings, or mineralized soil, which are uneconomic to extract by conventional methods [19]. The metal content of a bio-ore is usually much greater than that of a conventional ore and requires less storage space, despite the lower density of a bio-ore [173, 193]. Besides that, phytomining can also be used for remedial purposes to extract high concentrations of toxic metals, such as Nickel and Thallium, from mine tailings and other metal contaminated areas. Phytomining not only produces ingots of Gold but, interestingly and importantly, this technique can also be used to produce Gold nanoparticles, which is of huge potential to nanotechnology industries [211-213]. Additionally, phytomining provides a source of income from the sales of Carbon dioxide credits. Phytomining restores mined degraded land through the planting of hyperaccumulator species more quickly than natural revegetation which may take decades or even hundreds of years because it is dependent on animals and windborne seedlings. Phytomining also provides a potential energy storage that can be utilized to generate thermal energy, which is a cheap and renewable resource.

Phytomining of Nickel. Numerous studies have examined the use of Ni phytomining. The first field trials involving phytomining were carried out at the US Bureau of the Mines, Reno, Nevada, using the Ni hyperaccumulator Streptanthus polygaloides [184]. The findings of this initial research indicated that a yield of $100 \mathrm{~kg} /$ ha of sulfur-free Ni could be produced via phytomining [186, 193, 214]. Anderson and coworkers [193] tested the phytomining potential of $\mathrm{Ni}$ hyperaccumulator Alyssum bertolonii from Italy and Berkheya coddii from South Africa. In situ, an experiment for second field trials of Nickel phytomining using the Ni hyperaccumulator Alyssum bertolonii was performed in Tuscany, Italy [186]. In this experiment, the plants were fertilized with $\mathrm{N}+\mathrm{P}+\mathrm{K}$ combinations over a period of two years. The results indicated that the biomass of dry matter increased threefold to $9.0 \mathrm{t} / \mathrm{ha}$ and this was gained with $\mathrm{N}+\mathrm{P}+\mathrm{K}$ without dilution of unfertilized Ni concentrations. The existing research does not show a correlation between the age of a plant and Ni content. The hyperaccumulator Alyssum bertolonii has the potential to be used in Nickel phytomining of ultramafic soils. The hyperaccumulating plant Alyssum murale can accumulate up to $20,000 \mathrm{mg} \mathrm{kg}^{-1}$ dry weight, and a biomass of $10,000 \mathrm{~kg} / \mathrm{ha}$ can be harvested per year [182].

Phytomining of Gold. Gold is a valuable metal that is in high demand in commercial industries. It has a potential for phytomining where the aim of the operation is to yield an economic profit and/or exploit low-grade ore or mineralized 
soils that are too poor for conventional mining methods [215]. Conventional technology is generally unable to economically recover residual Gold, and, as such, phytomining offers a viable alternative method of recovering these valuable Gold resources [216]. Plant species do not naturally accumulate Gold; it needs to be made soluble in soils for enhancing uptake to occur. For this purpose, hyperaccumulation is induced by adding Sodium cyanide, thiocyanate, and thiosulphates. The residual Gold can be extracted using induced hyperaccumulation if the substrate were amenable to plant growth. The Gold concentration that can be induced into a plant is dependent on the Gold concentration in the soil in which the plant is growing. Induced hyperaccumulation to uptake Gold has been reported in numerous pieces of research. Anderson and coworkers [187] showed that approximately $2 \mathrm{mg} \mathrm{kg}^{-1}$ of Gold are needed to achieve $100 \mathrm{mg} \mathrm{kg}^{-1}$ of plant dry weight in Indian mustard (Brassica juncea) with adding ammonium thiocyanate $\left(\mathrm{NH}_{4} \mathrm{SCN}\right)$ at different rates of $0,80,160,320$, and $640 \mathrm{mg} \mathrm{kg}^{-1}$ dry substrate weight in pots containing an artificial $5 \mathrm{mg} \mathrm{kg}^{-1}$ finely disseminated Gold rich material, analogous to natural, oxidized, and nonsulphidic ores. Msuya and coworkers [194] induced hyperaccumulation in the five root crops, carrot (Daucus carota), red beet (Beta vulgaris), onion (Allium cepa), and two cultivars of radish (Raphanus sativus) with $\mathrm{NH}_{4} \mathrm{SCN}$ and ammonium thiosulphate $\left[\left(\mathrm{NH}_{4}\right)_{2} \mathrm{~S}_{2} \mathrm{O}_{3}\right]$ in substrates containing $3.8 \mathrm{mg} \mathrm{kg}^{-1}$ Gold. The results showed that the roots in all five crops contained higher metal concentrations than their shoots.

Phytomining of Thallium. Thallium has the biggest economic potential after Gold, Platinum, and Palladium because it is relatively naturally unavailable. Leblanc and coworkers [196] discovered unusually high hyperaccumulation of $\mathrm{Tl}$ by Iberis intermedia Guersent and Biscutella laevigata L. growing over Lead/Zinc mine tailings in southern France. Tailings typically contained 15,000 $\mathrm{mg} \mathrm{kg}^{-1} \mathrm{Zn}, 5,000 \mathrm{mg} \mathrm{kg}^{-1} \mathrm{~Pb}$, and, locally, up to $40 \mathrm{mg} \mathrm{kg}^{-1} \mathrm{Tl}$. Their results indicated that the content of Thallium in Iberis intermedia was more than $4,000 \mathrm{mg} \mathrm{kg}^{-1}$ in the whole plant dry weight with a biomass of $10,000 \mathrm{~kg} / \mathrm{ha}$, while in the Biscutella laevigata the content of Thallium was over $14,000 \mathrm{mg} \mathrm{kg}^{-1}$ with a biomass of $4,000 \mathrm{~kg} / \mathrm{ha}$. Biscutella laevigata at $4 \mathrm{t} / \mathrm{ha}$ has less than half of the biomass of Iberis intermedia but three times the Thallium mean concentration (mean $10 \mathrm{mg} \mathrm{kg}^{-1}$ ). These results are similar to those reported in field trials in New Zealand, where a biomass of $10,000 \mathrm{~kg} / \mathrm{ha}$ was found in Iberis intermedia by Anderson and coworkers [193]. The hyperaccumulator plant produces about $700 \mathrm{~kg} / \mathrm{ha}$ of bio-ore and $8 \mathrm{~kg}$ of Thallium, which was worth US\$2400 at a world price of US\$ $300 / \mathrm{kg}$. A crop biomass of $10 \mathrm{t} / \mathrm{ha}$ of Iberis intermedia was found from field observations in France and field trials in New Zealand and this indicates that there is a potential to phytomine Thallium if sufficiently large areas of contaminated soils are available and large-scale production advantages can be acquired [193].

2.6. Biomineralization. The collective process by which organisms form minerals is called biomineralization [217].
Metal-mineral-microbe interactions are basically microbial biomineralization processes [4]. More than 70 different minerals are produced by organisms via biomineralization [218]. The preparation of biosorption is also important for estimating the operational costs associated with phytomining.

\section{The Potential of Products Derived via Bioremediation from Heavy Metal Industry Effluents for High Technology Applications}

3.1. Nanotechnology Applications. Metal nanoparticles, such as Gold, Silver, and Platinum, have become fundamental building blocks of nanotechnology [219]. The properties, morphology, surface area, structure, and shape of nanoparticles make them ideal for preparing nanostructured materials and devices [75, 220, 221]. Metal nanoparticles are crystalline in nature $[56,57]$. To control the size, shape, and stability of nanoparticles, different synthesis conditions are applied [56].

Nanotechnology is an interdisciplinary area of science, economy, engineering, and industry, and increasing attention is being placed on the production of nanoparticles. Nanotechnologies use different metal nanoparticles in a wide range of sizes and shapes. Nanoparticles (nanocrystals, Carbon nanotubes, etc.) are microscopic particles. They are usually between 1 and $100 \mathrm{~nm}$ in size in each spatial dimension and are considered to be the building blocks of the next generation of optoelectronics, electronics, and various chemical and biochemical sensors. A variety of nanomaterials are at various stages of research and development, each one possessing unique functionalities that are potentially applicable to the remediation of industrial effluents, groundwater, surface water, and drinking water. Silver nanomaterials are the most interactive in the application of nanotechnology. Silver nanoparticles can be used in the development of antibacterial water filters for the treatment of waters [222]. Tran and coworkers [223] reviewed Silver nanoparticles in depth and assessed synthesis, antibacterial effects, toxicology to humans and the environment, current applications, and future prospects. Silver nanoparticles are of great interest due to their optical, electrical, and antimicrobial properties [224].

3.2. Sustainable Green Metal Mining. In recent decades, techniques for mining metals using plants-phytomininghave offered scientists the possibility to extract metals from low-grade ores, overburdens, mill tailings, or mineralized soil that would be uneconomical to mine using conventional methods [19]. Plant hyperaccumulators accumulate large amounts of metals in their roots, such as Nickel and Thallium, and hence provide a potential route for soil remediation and for the recovery and reuse of the metal [193]. Phytomining not only produces ingots of Gold but, interestingly and importantly, this technique can also be used to produce Gold nanoparticles, which are of huge potential to nanotechnology industries [211-213]. The biological systems that are used in the synthesis of nanoparticles exhibit water-soluble and biocompatible properties that are essential for many field applications, from medicine to electronics [76]. A variety of microorganisms, plants, and plant parts, including roots, 
stems, leaves, and bark, provide low-cost, energy efficient, and nontoxic methods of synthesizing nanoparticles. Heavy metals can be removed from contaminated soil and water via hyperaccumulation, either through phytoremediation or through phytomining, for later use as material productions in nanotechnology.

\section{Conclusion}

This work reviewed existing research that examines the potential of the bioremediation process for recovery of heavy metals from contaminated water and soil sources. The use of cheap and easily obtained biomass using this approach offers a low-cost and environmentally friendly solution and has the potential to be used for large-scale bioremediation. Biosorption-based bioremediation represents a low-cost and environmentally friendly method of metal recovery that may offer a means of avoiding metal depletion. The bioremediation process proposed could produce metal nanoparticles through biosorption-based biosynthesis, which also uses the biomass from plants and microorganisms. Metal nanoparticles are very important for high technology applications, such as biomedical applications, sensors, MEMS (microelectromechanical systems) and NEMS (nanoelectromechanical systems), catalysts, and antimicrobial agents. Phytomining is an environmentally friendly method of removing heavy metals from wastewaters and soil. This method is important, especially in areas in which the soil contains high levels of heavy metals.

Based on the past and present works of research in bioremediation and phytomining processes, the future of such attempts looks bright. Regarding the conversion of heavy metal effluents from waste material to a valuable resource for research, development, and industry, there is still a plenitude of basic research that needs to be performed to establish the basics, especially concerning which plants can be used on which soils with which pollutant concentration and in which environment (e.g., other plants and microbiome communities, latitude, and longitude).

The continuous implementation of both bioremediation and phytomining processes offers great benefits of green methods in various fields, such as environment, resources, economy, and human life. Comprehensive research and development for improvement of both processes promise a bright future for successful implementation of biomimetic approaches in resource management.

\section{Conflict of Interests}

The authors declare that there is no conflict of interests regarding the publication of this paper.

\section{Acknowledgment}

This work was supported by the Fundamental Research Grant Scheme from the Ministry of Higher Education, Malaysia (project no. FRGS/1/2013/TK02/UKM/01/1).

\section{References}

[1] I. C. Gebeshuber, B. Y. Majlis, and H. Stachelberger, "Tribology in biology: biomimetic studies across dimensions and across fields," International Journal of Mechanical and Materials Engineering, vol. 4, no. 3, pp. 321-327, 2009.

[2] W. H. Rulkens, R. Tichy, and J. T. C. Grotenhuis, "Remediation of polluted soil and sediment: perspectives and failures," Water Science and Technology, vol. 37, no. 8, pp. 27-35, 1998.

[3] C. Garbisu and I. Alkorta, "Review: basic concepts on heavy metal soil bioremediation," The European Journal of Mineral Processing and Environmental Protection, vol. 3, pp. 58-66, 2003.

[4] G. M. Gadd, "Metals, minerals and microbes: geomicrobiology and bioremediation," Microbiology, vol. 156, no. 3, pp. 609-643, 2010.

[5] S. Bhatnagar and R. Kumari, "Bioremediation: a sustainable tool for environmental management-a review," Annual Review \& Research in Biology, vol. 3, no. 4, pp. 974-993, 2013.

[6] F. Fu and Q. Wang, "Removal of heavy metal ions from wastewaters: a review," Journal of Environmental Management, vol. 92, no. 3, pp. 407-418, 2011.

[7] M. A. Hashim, S. Mukhopadhyay, J. N. Sahu, and B. Sengupta, "Remediation technologies for heavy metal contaminated groundwater," Journal of Environmental Management, vol. 92, no. 10, pp. 2355-2388, 2011.

[8] A. Malik, "Metal bioremediation through growing cells," Environment International, vol. 30, no. 2, pp. 261-278, 2004.

[9] Churngold Group, Heavy Metal Contamination, 2014.

[10] B. W. Atkinson, F. Bux, and H. C. Kasan, "Considerations for application of biosorption technology to remediate metalcontaminated industrial effluents," Water $S A$, vol. 24, no. 2, pp. 129-135, 1998.

[11] R. Dhankhar and R. B. Guriyan, "Bacterial biosorbents for detoxification of heavy metals from aqueous solution: a review," International Journal of Advances in Science and Technology, vol. 2, pp. 103-128, 2011.

[12] K. Vijayaraghavan and Y.-S. Yun, "Bacterial biosorbents and biosorption," Biotechnology Advances, vol. 26, no. 3, pp. 266-291, 2008.

[13] J. He and J. P. Chen, "A comprehensive review on biosorption of heavy metals by algal biomass: materials, performances, chemistry, and modeling simulation tools," Bioresource Technology, vol. 160, pp. 67-78, 2014.

[14] A. V. Bankar, S. S. Zinjarde, B. P. Kapadnis, T. Satyanarayana, B. N. Johri, and A. Prakash, "Management of heavy metal pollution by using yeast biomass," in Microorganisms in Environmental Management, pp. 335-363, Springer, Berlin, Germany, 2012.

[15] T. Viraraghavan and A. Srinivasan, "Fungal biosorption and biosorbents," in Microbial Biosorption of Metals, P. Kotrba, M. Mackova, and T. Macek, Eds., pp. 143-158, Springer, Dordrecht, Netherlands, 2011.

[16] T. A. H. Nguyen, H. H. Ngo, W. S. Guo et al., "Applicability of agricultural waste and by-products for adsorptive removal of heavy metals from wastewater," Bioresource Technology, vol. 148, pp. 574-585, 2013.

[17] S. M. Shaheen, F. I. Eissa, K. M. Ghanem, H. M. Gamal ElDin, and F. S. Al Anany, "Heavy metals removal from aqueous solutions and wastewaters by using various byproducts," Journal of Environmental Management, vol. 128, pp. 514-521, 2013.

[18] A. Bhatnagar and M. Sillanpää, "Utilization of agro-industrial and municipal waste materials as potential adsorbents for water 
treatment-a review," Chemical Engineering Journal, vol. 157, no. 2-3, pp. 277-296, 2010.

[19] T. V. Nedelkoska and P. M. Doran, "Hyperaccumulation of cadmium by hairy roots of Thlaspicaerulescens," Biotechnology and Bioengineering, vol. 67, pp. 607-615, 2000.

[20] S. Babel and T. A. Kurniawan, "Low-cost adsorbents for heavy metals uptake from contaminated water: a review," Journal of Hazardous Materials, vol. 97, no. 1-3, pp. 219-243, 2003.

[21] P. N. Dave and L. V. Chopda, "Application of iron oxide nanomaterials for the removal of heavy metals," Journal of Nanotechnology, vol. 2014, Article ID 398569, 14 pages, 2014.

[22] L. S. Acosta-Torres, L. M. Lpez-Marín, R. E. Núñez-Anita, G. Hernández-Padrón, and V. M. Castaño, "Biocompatible metaloxide nanoparticles: nanotechnology improvement of conventional prosthetic acrylic resins," Journal of Nanomaterials, vol. 2011, Article ID 941561, 8 pages, 2011.

[23] S. S. Ahluwalia and D. Goyal, "Microbial and plant derived biomass for removal of heavy metals from wastewater," Bioresource Technology, vol. 98, no. 12, pp. 2243-2257, 2007.

[24] C. Li, W. Jiang, N. Ma et al., "Bioaccumulation of cadmium by growing Zygosaccharomyces rouxii and Saccharomyces cerevisiae," Bioresource Technology, vol. 155, pp. 116-121, 2014.

[25] A. M. A. Abdallah, M. A. Abdallah, A. Beltagy, and E. Siam, "Contents of heavy metals in marine algae from Egyptian Red Sea coast," Toxicological and Environmental Chemistry, vol. 88, no. 1, pp. 9-22, 2006.

[26] D. R. Lovley, "Dissimilatory metal reduction," Annual Review of Microbiology, vol. 47, pp. 263-290, 1993.

[27] N. Durán, "Use of nanoparticles in soil-water bioremediation processes," in Proceedings of the 5th International Symposium (ISMOM '08), Pucón, Chile, 2008.

[28] D. R. Majumder, "Bioremediation: copper nanoparticles from electronic-waste," International Journal of Engineering Science and Technology, vol. 4, no. 10, pp. 4380-4389, 2014.

[29] T. A. Khan, M. Nazir, I. Ali, and A. Kumar, "Removal of Chromium(VI) from aqueous solution using guar gum-nano zinc oxide biocomposite adsorbent," Arabian Journal of Chemistry, 2013.

[30] N. Tamilselvan, K. Saurav, and K. Kannabiran, "Biosorption of selected toxic heavy metals using algal species Acanthopora spicefera," Pharmacologyonline, vol. 1, pp. 518-528, 2011.

[31] D. E. Salt, M. Blaylock, N. P. B. A. Kumar et al., "Phytoremediation: a novel strategy for the removal of toxic metals from the environment using plants," Bio/Technology, vol. 13, no. 5, pp. 468-474, 1995.

[32] I. Raskin, P. B. A. N. Kumar, S. Dushenkov, and D. E. Salt, "Bioconcentration of heavy metals by plants," Current Opinion in Biotechnology, vol. 5, no. 3, pp. 285-290, 1994.

[33] D. E. Salt, R. D. Smith, and I. Raskin, "Phytoremediation," Annual Review of Plant Physiology and Plant Molecular Biology, vol. 49, pp. 643-668, 1998.

[34] W. N. C. Anderson, "Hyperaccumulation by plants," in Element Recovery and Sustainability, A. J. Hunt, Ed., Royal Society of Chemistry, 2013.

[35] E. Masarovičová and K. Králová, "Plant-heavy metal interaction: Phytoremediation, Biofortification and Nanoparticles," in Advances in Selected Plant Physiology Aspects, G. Montanaro, Ed., In-Tech, Rijeka, Croatia, 2012.

[36] A. K. Gupta, S. Dwivedi, S. Sinha, R. D. Tripathi, U. N. Rai, and S. N. Singh, "Metal accumulation and growth performance of Phaseolus vulgaris grown in fly ash amended soil," Bioresource Technology, vol. 98, no. 17, pp. 3404-3407, 2007.
[37] M. L. Guerinot and D. E. Salt, "Fortified foods and phytoremediation: two sides of the same coin," Plant Physiology, vol. 125, no. 1, pp. 164-167, 2001.

[38] T. J. Beveridge and R. G. E. Murray, "Uptake and retention of metals by cell walls of Bacillus subtilis," Journal of Bacteriology, vol. 127, no. 3, pp. 1502-1518, 1976.

[39] T. J. Beveridge and W. S. Fyfe, "Metal fixation by bacterial cell walls," Canadian Journal of Earth Sciences, vol. 22, no. 12, pp. 1893-1898, 1985.

[40] T. A. Davis, B. Volesky, and A. Mucci, "A review of the biochemistry of heavy metal biosorption by brown algae," Water Research, vol. 37, no. 18, pp. 4311-4330, 2003.

[41] B. Volesky and Z. R. Holan, "Biosorption of heavy metals," Biotechnology Progress, vol. 11, no. 3, pp. 235-250, 1995.

[42] T. M. Roane, K. L. Josephson, and I. L. Pepper, "Dual-bioaugmentation strategy to enhance remediation of cocontaminated soil," Applied and Environmental Microbiology, vol. 67, no. 7, pp. 3208-3215, 2001.

[43] T. Srinath, T. Verma, P. W. Ramteke, and S. K. Garg, "Chromium (VI) biosorption and bioaccumulation by chromate resistant bacteria," Chemosphere, vol. 48, no. 4, pp. 427-435, 2002.

[44] M. Fomina and G. M. Gadd, "Biosorption: current perspectives on concept, definition and application," Bioresource Technology, vol. 160, pp. 3-14, 2014.

[45] H. Guha, K. Jayachandran, and F. Maurrasse, "Microbiological reduction of chromium(VI) in presence of pyrolusite-coated sand by Shewanella alga Simidu ATCC 55627 in laboratory column experiments," Chemosphere, vol. 52, no. 1, pp. 175-183, 2003.

[46] Z. Chen, Z. Huang, Y. Cheng et al., "Cr(VI) uptake mechanism of Bacillus cereus," Chemosphere, vol. 87, no. 3, pp. 211-216, 2012.

[47] Z. He, F. Gao, T. Sha, Y. Hu, and C. He, "Isolation and characterization of a Cr(VI)-reduction Ochrobactrum sp. strain CSCr-3 from chromium landfill," Journal of Hazardous Materials, vol. 163, no. 2-3, pp. 869-873, 2009.

[48] A. G. Tekerlekopoulou, M. Tsiflikiotou, L. Akritidou et al., "Modelling of biological $\mathrm{Cr}(\mathrm{VI})$ removal in draw-fill reactors using microorganisms in suspended and attached growth systems," Water Research, vol. 47, no. 2, pp. 623-636, 2013.

[49] V. Somasundaram, L. Philip, and S. M. Bhallamudi, "Experimental and mathematical modeling studies on $\mathrm{Cr}(\mathrm{VI})$ reduction by CRB, SRB and IRB, individually and in combination," Journal of Hazardous Materials, vol. 172, no. 2-3, pp. 606-617, 2009.

[50] T. Ahmad, I. A. Wani, N. Manzoor, J. Ahmed, and A. M. Asiri, "Biosynthesis, structural characterization and antimicrobial activity of gold and silver nanoparticles," Colloids and Surfaces B: Biointerfaces, vol. 107, pp. 227-234, 2013.

[51] A. R. Binupriya, M. Sathishkumar, K. Vijayaraghavan, and S.-I. Yun, "Bioreduction of trivalent aurum to nano-crystalline gold particles by active and inactive cells and cell-free extract of Aspergillus oryzae var. viridis," Journal of Hazardous Materials, vol. 177, no. 1-3, pp. 539-545, 2010.

[52] A. Mishra, S. K. Tripathy, and S.-I. Yun, "Fungus mediated synthesis of gold nanoparticles and their conjugation with genomic DNA isolated from Escherichia coli and Staphylococcus aureus," Process Biochemistry, vol. 47, no. 5, pp. 701-711, 2012.

[53] K. B. Narayanan and N. Sakthivel, "Facile green synthesis of gold nanostructures by NADPH-dependent enzyme from the extract of Sclerotium rolfsii," Colloids and Surfaces A: Physicochemical and Engineering Aspects, vol. 380, no. 1-3, pp. 156-161, 2011. 
[54] F. Cai, J. Li, J. Sun, and Y. Ji, "Biosynthesis of gold nanoparticles by biosorption using Magnetospirillum gryphiswaldense MSR-1," Chemical Engineering Journal, vol. 175, no. 1, pp. 70-75, 2011.

[55] S. A. Aromal and D. Philip, "Benincasa hispida seed mediated green synthesis of gold nanoparticles and its optical nonlinearity," Physica E: Low-Dimensional Systems and Nanostructures, vol. 44, no. 7-8, pp. 1329-1334, 2012.

[56] N. Kulkarni and U. Muddapur, "Biosynthesis of metal nanoparticles: a review," Journal of Nanotechnology, vol. 2014, Article ID 510246, 8 pages, 2014.

[57] M. Rai and A. Yadav, "Plants as potential synthesiser of precious metal nanoparticles: progress and prospects," IET Nanobiotechnology, vol. 7, no. 3, pp. 117-124, 2013.

[58] K. B. Narayanan and N. Sakthivel, "Biological synthesis of metal nanoparticles by microbes," Advances in Colloid and Interface Science, vol. 156, no. 1-2, pp. 1-13, 2010.

[59] Y. Wang, X. He, K. Wang, X. Zhang, and W. Tan, "Barbated Skullcup herb extract-mediated biosynthesis of gold nanoparticles and its primary application in electrochemistry," Colloids and Surfaces B: Biointerfaces, vol. 73, no. 1, pp. 75-79, 2009.

[60] A. J. Hunt, T. J. Farmer, and J. H. Clark, "Elemental sustainability and the importance of scarce element recovery," in Element Recovery and Sustainability, chapter 1, 2013.

[61] K. Pollmann, J. Raff, M. Merroun, K. Fahmy, and S. SelenskaPobell, "Metal binding by bacteria from uranium mining waste piles and its technological applications," Biotechnology Advances, vol. 24, no. 1, pp. 58-68, 2006.

[62] S. Wang and X. Zhao, "On the potential of biological treatment for arsenic contaminated soils and groundwater," Journal of Environmental Management, vol. 90, no. 8, pp. 2367-2376, 2009.

[63] D. Purkayastha, U. Mishra, and S. Biswas, "A comprehensive review on Cd(II) removal from aqueous solution," Journal of Water Process Engineering, vol. 2, pp. 105-128, 2014.

[64] S. Islamoglu, L. Yilmaz, and H. O. Ozbelge, "Development of a precipitation based separation scheme for selective removal and recovery of heavy metals from cadmium rich electroplating industry effluents," Separation Science and Technology, vol. 41, no. 15, pp. 3367-3385, 2006.

[65] A. Saeed and M. Iqbal, "Bioremoval of cadmium from aqueous solution by black gram husk (Cicer arientinum)," Water Research, vol. 37, no. 14, pp. 3472-3480, 2003.

[66] J. Shah, M. R. Jan, A. U. Haq Atta Ul, and M. Sadia, "Biosorption of cadmium from aqueous solution using mulberry wood sawdust: equilibrium and kinetic studies," Separation Science and Technology, vol. 46, no. 10, pp. 1631-1637, 2011.

[67] C. P. J. Isaac and A. Sivakumar, "Removal of lead and cadmium ions from water using Annona squamosa shell: kinetic and equilibrium studies," Desalination and Water Treatment, vol. 51, no. 40-42, pp. 7700-7709, 2013.

[68] J.-S. Chang, R. Law, and C.-C. Chang, "Biosorption of lead, copper and cadmium by biomass of Pseudomonas aeruginosa PU21," Water Research, vol. 31, no. 7, pp. 1651-1658, 1997.

[69] H. Ni, Z. Xiong, T. Ye, Z. Zhang, X. Ma, and L. Li, "Biosorption of copper(II) from aqueous solutions using volcanic rock matrix-immobilized Pseudomonas putida cells with surfacedisplayed cyanobacterial metallothioneins," Chemical Engineering Journal, vol. 204-205, pp. 264-271, 2012.

[70] A. Hammaini, F. González, A. Ballester, M. L. Blázquez, and J. A. Muñoz, "Biosorption of heavy metals by activated sludge and their desorption characteristics," Journal of Environmental Management, vol. 84, no. 4, pp. 419-426, 2007.
[71] W.-B. Lu, J.-J. Shi, C.-H. Wang, and J.-S. Chang, "Biosorption of lead, copper and cadmium by an indigenous isolate Enterobacter sp. J1 possessing high heavy-metal resistance," Journal of Hazardous Materials, vol. 134, no. 1-3, pp. 80-86, 2006.

[72] W.-J. Liu, F.-X. Zeng, H. Jiang, X.-S. Zhang, and H.-Q. Yu, "Techno-economic evaluation of the integrated biosorptionpyrolysis technology for lead $(\mathrm{Pb})$ recovery from aqueous solution," Bioresource Technology, vol. 102, no. 10, pp. 62606265, 2011.

[73] K. N. Thakkar, S. S. Mhatre, and R. Y. Parikh, "Biological synthesis of metallic nanoparticles," Nanomedicine: Nanotechnology, Biology, and Medicine, vol. 6, no. 2, pp. 257-262, 2010.

[74] A. K. Mittal, Y. Chisti, and U. C. Banerjee, "Synthesis of metallic nanoparticles using plant extracts," Biotechnology Advances, vol. 31, no. 2, pp. 346-356, 2013.

[75] S. Gupta, K. Sharma, and R. Sharma, "Myconanotechnology and application of nanoparticles in biology," Recent Research in Science and Technology, vol. 4, no. 8, pp. 36-38, 2012.

[76] N. Krumov, I. Perner-Nochta, S. Oder, V. Gotcheva, A. Angelov, and C. Posten, "Production of inorganic nanoparticles by microorganisms," Chemical Engineering and Technology, vol. 32, no. 7, pp. 1026-1035, 2009.

[77] K. V. Pavani, N. Sunil Kumar, and K. Gayathramma, "Plants as ecofriendly nanofactories," Journal of Bionanoscience, vol. 6, no. 1, pp. 1-6, 2012.

[78] S. Baker, B. P. Harini, D. Rakshith, and S. Satish, "Marine microbes: invisible nanofactories," Journal of Pharmacy Research, vol. 6, pp. 383-388, 2013.

[79] N. Duran, D. P. Marcato, A. Ingle, A. Gade, and M. Rai, "Fungimediated synthesis of silver nanoparticles: characterization processes and applications," in Progress in Mycology, M. Rai and G. Kövics, Eds., pp. 425-449, Scientific Publishers, Jodhpur, India, 2010.

[80] S. Baker, D. Rakshith, K. S. Kavitha et al., "Plants: emerging as nanofactories towards facile route in synthesis of nanoparticles," BioImpacts, vol. 3, no. 3, pp. 111-117, 2013.

[81] V. Parashar, R. Parashar, B. Sharma, and A. C. Pandey, "Parthenium leaf extract mediated synthesis of silver nanoparticles: a novel approach towards weed utilization," Digest Journal of Nanomaterials and Biostructures, vol. 4, no. 1, pp. 45-50, 2009.

[82] K. S. Prasad, H. Patel, T. Patel, K. Patel, and K. Selvaraj, "Biosynthesis of Se nanoparticles and its effect on UV-induced DNA damage," Colloids and Surfaces B: Biointerfaces, vol. 103, pp. 261-266, 2013.

[83] X. Weng, L. Huang, Z. Chen, M. Megharaj, and R. Naidu, "Synthesis of iron-based nanoparticles by green tea extract and their degradation of malachite," Industrial Crops and Products, vol. 51, pp. 342-347, 2013.

[84] G. Rajakumar, A. A. Rahuman, B. Priyamvada, V. G. Khanna, D. K. Kumar, and P. J. Sujin, "Eclipta prostrata leaf aqueous extract mediated synthesis of titanium dioxide nanoparticles," Materials Letters, vol. 68, pp. 115-117, 2012.

[85] G. K. Naik, P. M. Mishra, and K. Parida, "Green synthesis of Au/ $\mathrm{TiO}_{2}$ for effective dye degradation in aqueous system," Chemical Engineering Journal, vol. 229, pp. 492-497, 2013.

[86] B. Zheng, T. Kong, X. Jing et al., "Plant-mediated synthesis of platinum nanoparticles and its bioreductive mechanism," Journal of Colloid and Interface Science, vol. 396, pp. 138-145, 2013.

[87] V. Vignesh, K. Felix Anbarasi, S. Karthikeyeni, G. Sathiyanarayanan, P. Subramanian, and R. Thirumurugan, "A superficial phyto-assisted synthesis of silver nanoparticles and their 
assessment on hematological and biochemical parameters in Labeo rohita (Hamilton, 1822)," Colloids and Surfaces A: Physicochemical and Engineering Aspects, vol. 439, pp. 184-192, 2013.

[88] M. S. Abdel-Aziz, M. S. Shaheen, A. A. El-Nekeety, and M. A. Abdel-Wahhab, "Antioxidant and antibacterial activity of silver nanoparticles biosynthesized using Chenopodium murale leaf extract," Journal of Saudi Chemical Society, vol. 18, no. 4, pp. 356-363, 2014.

[89] A. J. Kora, R. B. Sashidhar, and J. Arunachalam, "Aqueous extract of gum olibanum (Boswellia serrata): a reductant and stabilizer for the biosynthesis of antibacterial silver nanoparticles," Process Biochemistry, vol. 47, no. 10, pp. 1516-1520, 2012.

[90] V. Gopinath, S. Priyadarshini, N. Meera Priyadharsshini, K. Pandian, and P. Velusamy, "Biogenic synthesis of antibacterial silver chloride nanoparticles using leaf extracts of Cissus quadrangularis Linn," Materials Letters, vol. 91, pp. 224-227, 2013.

[91] Y. Zhang, X. Cheng, Y. Zhang, X. Xue, and Y. Fu, "Biosynthesis of silver nanoparticles at room temperature using aqueous aloe leaf extract and antibacterial properties," Colloids and Surfaces A: Physicochemical and Engineering Aspects, vol. 423, pp. 63-68, 2013.

[92] V. Gopinath, D. MubarakAli, S. Priyadarshini, N. M. Priyadharsshini, N. Thajuddin, and P. Velusamy, "Biosynthesis of silver nanoparticles from Tribulus terrestris and its antimicrobial activity: a novel biological approach," Colloids and Surfaces B: Biointerfaces, vol. 96, pp. 69-74, 2012.

[93] M. Yilmaz, H. Turkdemir, M. A. Kilic et al., "Biosynthesis of silver nanoparticles using leaves of Stevia rebaudiana," Materials Chemistry and Physics, vol. 130, no. 3, pp. 1195-1202, 2011.

[94] M. Vijayakumar, K. Priya, F. T. Nancy, A. Noorlidah, and A. B. A. Ahmed, "Biosynthesis, characterisation and anti-bacterial effect of plant-mediated silver nanoparticles using Artemisia nilagirica," Industrial Crops and Products, vol. 41, no. 1, pp. 235240, 2013

[95] T. Y. Suman, S. R. Radhika Rajasree, A. Kanchana, and S. B. Elizabeth, "Biosynthesis, characterization and cytotoxic effect of plant mediated silver nanoparticles using Morinda citrifolia root extract," Colloids and Surfaces B: Biointerfaces, vol. 106, pp. 74-78, 2013.

[96] J. J. Antony, P. Sivalingam, D. Siva et al., "Comparative evaluation of antibacterial activity of silver nanoparticles synthesized using Rhizophora apiculata and glucose," Colloids and Surfaces B: Biointerfaces, vol. 88, no. 1, pp. 134-140, 2011.

[97] K. Raja, A. Saravanakumar, and R. Vijayakumar, "Efficient synthesis of silver nanoparticles from Prosopis juliflora leaf extract and its antimicrobial activity using sewage," Spectrochimica Acta A: Molecular and Biomolecular Spectroscopy, vol. 97, pp. 490494, 2012.

[98] M. M. H. Khalil, E. H. Ismail, K. Z. El-Baghdady, and D. Mohamed, "Green synthesis of silver nanoparticles using olive leaf extract and its antibacterial activity," Arabian Journal of Chemistry, 2013.

[99] T. J. I. Edison and M. G. Sethuraman, "Instant green synthesis of silver nanoparticles using Terminalia chebula fruit extract and evaluation of their catalytic activity on reduction of methylene blue," Process Biochemistry, vol. 47, no. 9, pp. 1351-1357, 2012.

[100] S. M. Roopan, G. Madhumitha, A. A. Rahuman, C. Kamaraj, A. Bharathi, and T. V. Surendra, "Low-cost and eco-friendly phyto-synthesis of silver nanoparticles using Cocos nucifera coir extract and its larvicidal activity," Industrial Crops and Products, vol. 43, no. 1, pp. 631-635, 2013.
[101] M. F. Zayed, W. H. Eisa, and A. A. Shabaka, "Malva parviflora extract assisted green synthesis of silver nanoparticles," Spectrochimica Acta A: Molecular and Biomolecular Spectroscopy, vol. 98, pp. 423-428, 2012.

[102] D. Philip, "Mangifera Indica leaf-assisted biosynthesis of welldispersed silver nanoparticles," Spectrochimica Acta A: Molecular and Biomolecular Spectroscopy, vol. 78, no. 1, pp. 327-331, 2011.

[103] N. Yang and W.-H. Li, "Mango peel extract mediated novel route for synthesis of silver nanoparticles and antibacterial application of silver nanoparticles loaded onto non-woven fabrics," Industrial Crops and Products, vol. 48, pp. 81-88, 2013.

[104] R. Sankar, A. Karthik, A. Prabu, S. Karthik, K. S. Shivashangari, and V. Ravikumar, "Origanum vulgare mediated biosynthesis of silver nanoparticles for its antibacterial and anticancer activity," Colloids and Surfaces B: Biointerfaces, vol. 108, pp. 80-84, 2013.

[105] K. Mallikarjuna, N. John Sushma, G. Narasimha, L. Manoj, and B. Deva Prasad Raju, "Phytochemical fabrication and characterization of silver nanoparticles by using Pepper leaf broth," Arabian Journal of Chemistry, 2012.

[106] R. Arunachalam, S. Dhanasingh, B. Kalimuthu, M. Uthirappan, C. Rose, and A. B. Mandal, "Phytosynthesis of silver nanoparticles using Coccinia grandis leaf extract and its application in the photocatalytic degradation," Colloids and Surfaces B: Biointerfaces, vol. 94, pp. 226-230, 2012.

[107] V. S. Kotakadi, Y. S. Rao, S. A. Gaddam, T. N. V. K. V. Prasad, A. V. Reddy, and S. Gopal, "Simple and rapid biosynthesis of stable silver nanoparticles using dried leaves of Catharanthus roseus. Linn. G. Donn and its anti microbial activity," Colloids and Surfaces B: Biointerfaces, vol. 105, pp. 194-198, 2013.

[108] N. Basavegowda and Y. R. Lee, "Synthesis of silver nanoparticles using Satsuma mandarin (Citrus unshiu) peel extract: a novel approach towards waste utilization," Materials Letters, vol. 109, pp. 31-33, 2013.

[109] C. Tamuly, M. Hazarika, and M. Bordoloi, "Biosynthesis of $\mathrm{Au}$ nanoparticles by Gymnocladus assamicus and its catalytic activity," Materials Letters, vol. 108, pp. 276-279, 2013.

[110] K. Sneha, M. Sathishkumar, S. Kim, and Y.-S. Yun, "Counter ions and temperature incorporated tailoring of biogenic gold nanoparticles," Process Biochemistry, vol. 45, no. 9, pp. 1450$1458,2010$.

[111] L. Castro, M. L. Blázquez, F. González, J. A. Muñoz, and A. Ballester, "Extracellular biosynthesis of gold nanoparticles using sugar beet pulp," Chemical Engineering Journal, vol. 164, no. 1, pp. 92-97, 2010.

[112] S. U. Ganaie, T. Abbasi, J. Anuradha, and S. A. Abbasi, "Biomimetic synthesis of silver nanoparticles using the amphibious weed ipomoea and their application in pollution control," Journal of King Saud University, vol. 26, no. 3, pp. 222-229, 2014.

[113] P. Lodeiro and M. Sillanpää, "Gold reduction in batch and column experiments using silica gel derivates and seaweed biomass," Chemical Engineering Journal, vol. 230, pp. 372-379, 2013.

[114] I. K. Sen, K. Maity, and S. S. Islam, "Green synthesis of gold nanoparticles using a glucan of an edible mushroom and study of catalytic activity," Carbohydrate Polymers, vol. 91, no. 2, pp. 518-528, 2013.

[115] K. P. Kumar, W. Paul, and C. P. Sharma, "Green synthesis of gold nanoparticles with Zingiber officinale extract: characterization and blood compatibility," Process Biochemistry, vol. 46, no. 10, pp. 2007-2013, 2011. 
[116] R. Vijayakumar, V. Devi, K. Adavallan, and D. Saranya, “Green synthesis and characterization of gold nanoparticles using extract of anti-tumor potent Crocus sativus," Physica E: LowDimensional Systems and Nanostructures, vol. 44, no. 3, pp. 665671, 2011.

[117] D. Philip, "Green synthesis of gold and silver nanoparticles using Hibiscus rosa sinensis," Physica E: Low-Dimensional Systems and Nanostructures, vol. 42, no. 5, pp. 1417-1424, 2010.

[118] N. Gupta, H. P. Singh, and R. K. Sharma, "Single-pot synthesis: plant mediated gold nanoparticles catalyzed reduction of methylene blue in presence of stannous chloride," Colloids and Surfaces A: Physicochemical and Engineering Aspects, vol. 367, no. 1-3, pp. 102-107, 2010.

[119] S. M. Ghoreishi, M. Behpour, and M. Khayatkashani, "Green synthesis of silver and gold nanoparticles using Rosa damascena and its primary application in electrochemistry," Physica E: Low-Dimensional Systems and Nanostructures, vol. 44, no. 1, pp. 97-104, 2011.

[120] K. Sneha, M. Sathishkumar, J. Mao, I. S. Kwak, and Y.-S. Yun, "Corynebacterium glutamicum-mediated crystallization of silver ions through sorption and reduction processes," Chemical Engineering Journal, vol. 162, no. 3, pp. 989-996, 2010.

[121] J. P. da Costa, A. V. Girão, J. P. Lourenço, O. C. Monteiro, T. Trindade, and M. C. Costa, "Green synthesis of covellite nanocrystals using biologically generated sulfide: potential for bioremediation systems," Journal of Environmental Management, vol. 128, pp. 226-232, 2013.

[122] G.-Q. Chen, "Plastics completely synthesized by bacteria: polyhydroxyalkanoates," in Plastics from Bacteria: Natural Functions and Applications, vol. 14 of Microbiology Monographs, pp. 17-37, Springer, Berlin, Germany, 2010.

[123] P. Rogers, J.-S. Chen, and M. J. Zidwick, "Organic acid and solvent production," in The Prokaryotes, pp. 511-755, Springer, New York, NY, USA, 2006.

[124] J. O'Keeffe, “Environmental and industrial use of Bacillus subtilis," in Global Post, America's World News Site, 2014.

[125] D. N. Correa-Llantén, S. A. Muñoz-Ibacache, M. E. Castro, P. A. Muñoz, and J. M. Blamey, "Gold nanoparticles synthesized by Geobacillus sp. strain ID17 a thermophilic bacterium isolated from Deception Island, Antarctica," Microbial Cell Factories, vol. 12, no. 1, article 75, 2013.

[126] C. Malarkodi, S. Rajeshkumar, M. Vanaja, K. Paulkumar, G. Gnanajobitha, and G. Annadurai, "Eco-friendly synthesis and characterization of gold nanoparticles using Klebsiella pneumoniae," Journal of Nanostructure in Chemistry, vol. 3, article 30, 2013.

[127] L. Du, H. Jiang, X. Liu, and E. Wang, "Biosynthesis of gold nanoparticles assisted by Escherichia coli $\mathrm{DH} 5 \alpha$ and its application on direct electrochemistry of hemoglobin," Electrochemistry Communications, vol. 9, no. 5, pp. 1165-1170, 2007.

[128] P. Sanpui, S. B. Pandey, S. S. Ghosh, and A. Chattopadhyay, "Green fluorescent protein for in situ synthesis of highly uniform Au nanoparticles and monitoring protein denaturation," Journal of Colloid and Interface Science, vol. 326, no. 1, pp. 129$137,2008$.

[129] M. I. Husseiny, M. A. El-Aziz, Y. Badr, and M. A. Mahmoud, "Biosynthesis of gold nanoparticles using Pseudomonas aeruginosa," Spectrochimica Acta A: Molecular and Biomolecular Spectroscopy, vol. 67, no. 3-4, pp. 1003-1006, 2007.
[130] S. He, Z. Guo, Y. Zhang, S. Zhang, J. Wang, and N. Gu, "Biosynthesis of gold nanoparticles using the bacteria Rhodopseudomonas capsulata," Materials Letters, vol. 61, no. 18, pp. 39843987, 2007.

[131] P. Arunkumar, M. Thanalakshmi, P. Kumar, and K. Premkumar, "Micrococcus luteus mediated dual mode synthesis of gold nanoparticles: involvement of extracellular $\alpha$-amylase and cell wall teichuronic acid," Colloids and Surfaces B: Biointerfaces, vol. 103, pp. 517-522, 2013.

[132] A. Malhotra, K. Dolma, N. Kaur, Y. S. Rathore, S. Mayilraj, and A. R. Choudhury, "Biosynthesis of gold and silver nanoparticles using a novel marine strain of Stenotrophomonas," Bioresource Technology, vol. 142, pp. 727-731, 2013.

[133] P. J. Fesharaki, P. Nazari, M. Shakibaie et al., "Biosynthesis of selenium nanoparticles using Klebsiella pneumoniae and their recovery by a simple sterilization process," Brazilian Journal of Microbiology, vol. 41, no. 2, pp. 461-466, 2010.

[134] A. K. Jha and K. Prasad, "Biosynthesis of metal and oxide nanoparticles using Lactobacilli from yoghurt and probiotic spore tablets," Biotechnology Journal, vol. 5, no. 3, pp. 285-291, 2010.

[135] K. Kalimuthu, R. S. Babu, D. Venkataraman, M. Bilal, and S. Gurunathan, "Biosynthesis of silver nanocrystals by Bacillus licheniformis," Colloids and Surfaces B: Biointerfaces, vol. 65, no. 1, pp. 150-153, 2008.

[136] S. Sadhasivam, P. Shanmugam, and K. Yun, "Biosynthesis of silver nanoparticles by Streptomyces hygroscopicus and antimicrobial activity against medically important pathogenic microorganisms," Colloids and Surfaces B: Biointerfaces, vol. 81, no. 1, pp. 358-362, 2010.

[137] P. Sivalingam, J. J. Antony, D. Siva, S. Achiraman, and K. Anbarasu, "Mangrove Streptomyces sp. BDUKAS10 as nanofactory for fabrication of bactericidal silver nanoparticles," Colloids and Surfaces B: Biointerfaces, vol. 98, pp. 12-17, 2012.

[138] M. M. Ganesh Babu and P. Gunasekaran, "Production and structural characterization of crystalline silver nanoparticles from Bacillus cereus isolate," Colloids and Surfaces B: Biointerfaces, vol. 74, no. 1, pp. 191-195, 2009.

[139] X. Wei, M. Luo, W. Li et al., "Synthesis of silver nanoparticles by solar irradiation of cell-free Bacillus amyloliquefaciens extracts and $\mathrm{AgNO}_{3}$," Bioresource Technology, vol.103, no. 1, pp. 273-278, 2012.

[140] N. Srivastava and M. Mukhopadhyay, "Biosynthesis and structural characterization of selenium nanoparticles mediated by Zooglea ramigera," Powder Technology, vol. 244, pp. 26-29, 2013.

[141] T. Wang, L. Yang, B. Zhang, and J. Liu, "Extracellular biosynthesis and transformation of selenium nanoparticles and application in $\mathrm{H}_{2} \mathrm{O}_{2}$ biosensor," Colloids and Surfaces B: Biointerfaces, vol. 80, no. 1, pp. 94-102, 2010.

[142] Z. H. Dhoondia and H. Chakraborty, "Lactobacillus mediated synthesis of silver oxide nanoparticles," Nanomaterials and Nanotechnology, vol. 2, no. 1, article 15, 2012.

[143] A. Vishnu Kirthi, A. Abdul Rahuman, G. Rajakumar et al., "Biosynthesis of titanium dioxide nanoparticles using bacterium Bacillus subtilis," Materials Letters, vol. 65, no. 17-18, pp. 2745-2747, 2011.

[144] R. Usha, E. Prabu, M. Palaniswamy, C. K. Venil, and R. Rajendran, "Synthesis of metal oxide nano particles by streptomyces sp for development of antimicrobial textiles," Global Journal of Biotechnology and Biochemistry, vol. 5, no. 3, pp. 153-160, 2010. 
[145] V. Ca, S. Hirematha, and M. N. Chandraprabhab, "Green synthesis of $\mathrm{ZnO}$ nanoparticles by Calotropis gigantea," International Journal of Current Engineering and Technology, pp. 118120, 2013.

[146] K. Prasad and A. K. Jha, " $\mathrm{ZnO}$ nanoparticles: synthesis and adsorption study," Natural Science, vol. 1, pp. 129-135, 2009.

[147] E. Selvarajan and V. Mohanasrinivasan, "Biosynthesis and characterization of $\mathrm{ZnO}$ nanoparticles using Lactobacillus plantarum VITES07," Materials Letters, vol. 112, pp. 180-182, 2013.

[148] C. Jayaseelan, A. A. Rahuman, A. V. Kirthi et al., "Novel microbial route to synthesize $\mathrm{ZnO}$ nanoparticles using Aeromonas hydrophila and their activity against pathogenic bacteria and fungi," Spectrochimica Acta. Part A: Molecular and Biomolecular Spectroscopy, vol. 90, pp. 78-84, 2012.

[149] H. J. Bai, Z. M. Zhang, Y. Guo, and G. E. Yang, "Biosynthesis of cadmium sulfide nanoparticles by photosynthetic bacteria Rhodopseudomonas palustris," Colloids and Surfaces B: Biointerfaces, vol. 70, no. 1, pp. 142-146, 2009.

[150] N. Vigneshwaran, A. A. Kathe, P. V. Varadarajan, R. P. Nachane, and R. H. Balasubramanya, "Biomimetics of silver nanoparticles by white rot fungus, Phaenerochaete chrysosporium," Colloids and Surfaces B: Biointerfaces, vol. 53, no. 1, pp. 55-59, 2006.

[151] R. Sanghi and P. Verma, "Biomimetic synthesis and characterisation of protein capped silver nanoparticles," Bioresource Technology, vol. 100, no. 1, pp. 501-504, 2009.

[152] N. Vigneshwaran, N. M. Ashtaputre, P. V. Varadarajan, R. P. Nachane, K. M. Paralikar, and R. H. Balasubramanya, "Biological synthesis of silver nanoparticles using the fungus Aspergillus flavus," Materials Letters, vol. 61, no. 6, pp. 1413-1418, 2007.

[153] K. C. Bhainsa and S. F. D'Souza, "Extracellular biosynthesis of silver nanoparticles using the fungus Aspergillus fumigatus," Colloids and Surfaces B: Biointerfaces, vol. 47, no. 2, pp. 160-164, 2006.

[154] N. S. Shaligram, M. Bule, R. Bhambure et al., "Biosynthesis of silver nanoparticles using aqueous extract from the compactin producing fungal strain," Process Biochemistry, vol. 44, no. 8, pp. 939-943, 2009.

[155] D. S. Balaji, S. Basavaraja, R. Deshpande, D. B. Mahesh, B. K. Prabhakar, and A. Venkataraman, "Extracellular biosynthesis of functionalized silver nanoparticles by strains of Cladosporium cladosporioides fungus," Colloids and Surfaces B: Biointerfaces, vol. 68, no. 1, pp. 88-92, 2009.

[156] E. Castro-Longoria, A. R. Vilchis-Nestor, and M. AvalosBorja, "Biosynthesis of silver, gold and bimetallic nanoparticles using the filamentous fungus Neurospora crassa," Colloids and Surfaces B: Biointerfaces, vol. 83, no. 1, pp. 42-48, 2011.

[157] A. Ahmad, P. Mukherjee, S. Senapati et al., "Extracellular biosynthesis of silver nanoparticles using the fungus Fusarium oxysporum," Colloids and Surfaces B: Biointerfaces, vol. 28, no. 4, pp. 313-318, 2003.

[158] A. Syed and A. Ahmad, "Extracellular biosynthesis of platinum nanoparticles using the fungus Fusarium oxysporum," Colloids and Surfaces B: Biointerfaces, vol. 97, pp. 27-31, 2012.

[159] G. Rajakumar, A. A. Rahuman, S. M. Roopan et al., "Fungusmediated biosynthesis and characterization of $\mathrm{TiO}_{2}$ nanoparticles and their activity against pathogenic bacteria," Spectrochimica Acta. Part A: Molecular and Biomolecular Spectroscopy, vol. 91, pp. 23-29, 2012.

[160] S. A. Khan and A. Ahmad, "Phase, size and shape transformation by fungal biotransformation of bulk $\mathrm{TiO}_{2}$," Chemical Engineering Journal, vol. 230, pp. 367-371, 2013.
[161] A. Mashrai, H. Khanam, and R. N. Aljawf, "Biological synthesis of $\mathrm{ZnO}$ nanoparticles using C. albicans and studying their catalytic performance in the synthesis of steroidal pyrazolines," Arabian Journal of Chemistry, 2013.

[162] K. B. Narayanan and N. Sakthivel, "Synthesis and characterization of nano-gold composite using Cylindrocladium floridanum and its heterogeneous catalysis in the degradation of 4nitrophenol," Journal of Hazardous Materials, vol. 189, no. 1-2, pp. 519-525, 2011.

[163] F. Arockiya Aarthi Rajathi, C. Parthiban, V. Ganesh Kumar, and P. Anantharaman, "Biosynthesis of antibacterial gold nanoparticles using brown alga, Stoechospermum marginatum (kützing)," Spectrochimica Acta. Part A: Molecular and Biomolecular Spectroscopy, vol. 99, pp. 166-173, 2012.

[164] K. Sen, P. Sinha, and S. Lahiri, "Time dependent formation of gold nanoparticles in yeast cells: a comparative study," Biochemical Engineering Journal, vol. 55, no. 1, pp. 1-6, 2011.

[165] R. Selvakumar, N. Arul Jothi, V. Jayavignesh et al., "As(V) removal using carbonized yeast cells containing silver nanoparticles," Water Research, vol. 45, no. 2, pp. 583-592, 2011.

[166] N. Rascio and F. Navari-Izzo, "Heavy metal hyperaccumulating plants: how and why do they do it? And what makes them so interesting?" Plant Science, vol. 180, no. 2, pp. 169-181, 2011.

[167] S. Sagner, R. Kneer, G. Wanner, J. P. Cosson, B. Deus-Neumann, and M. H. Zenk, "Hyperaccumulation, complexation and distribution of nickel in Sebertia acuminata," Phytochemistry, vol. 47, no. 3, pp. 339-347, 1998.

[168] R. S. Boyd, "The defense hypothesis of elemental hyperaccumulation: Status, challenges and new directions," Plant and Soil, vol. 293, no. 1-2, pp. 153-176, 2007.

[169] R. R. Brooks, J. Lee, R. D. Reeves, and T. Jaffre, "Detection of nickeliferous rocks by analysis of herbarium specimens of indicator plants," Journal of Geochemical Exploration, vol. 7, pp. 49-57, 1977.

[170] R. Chaney, "Plant uptake of inorganic waste," in Land Treatment of Hazardous Wastes, pp. 50-76, 1983.

[171] R. D. Reeves, "Hyperaccumulation of trace elements by plant," in Phytoremediation of Metal-Contaminated Soils, J. L. Morel, G. Echevarria, and N. Goncharova, Eds., vol. 68 of Nato Science Series IV: Earth and Environmental Science, pp. 68-25, Springer, New York, NY, USA, 2006.

[172] S. D. Cunningham and W. R. Berti, "Remediation of contaminated soils with green plants: an overview," In Vitro Cellular \& Developmental Biology, vol. 29, no. 4, pp. 207-212, 1993.

[173] R. R. Brooks, M. F. Chambers, L. J. Nicks, and B. H. Robinson, "Phytomining," Trends in Plant Science, vol. 3, no. 9, pp. 359362, 1998.

[174] S. Wei, Y. Li, J. Zhan, S. Wang, and J. Zhu, “Tolerant mechanisms of Rorippa globosa (Turcz.) Thell. hyperaccumulating Cd explored from root morphology," Bioresource Technology, vol. 118, pp. 455-459, 2012.

[175] A. Baker and R. Brooks, "Terrestrial higher plants which hyperaccumulate metallic elements-a review of their distribution, ecology and phytochemistry," Biorecovery, vol. 1, pp. 81-126, 1989.

[176] R. Chaney, M. Mallik, Y. Li, S. Brown, and E. Brewer, "Phytoremediation of soil metals," Current Opinion in Biotechnology, vol. 8, no. 3, pp. 279-284, 1997.

[177] L. Q. Ma, K. M. Komar, C. Tu, W. H. Zhang, Y. Cai, and E. D. Kennelley, "A fern that hyperaccumulates arsenic," Nature, vol. 409, article 579, 2001. 
[178] S. Wei, Q. Zhou, X. Wang, K. Zhang, G. Guo, and L. Q. Ma, "A newly-discovered Cd-hyperaccumulator Solanum nigrum L," Chinese Science Bulletin, vol. 50, no. 1, pp. 33-38, 2005.

[179] T. Jaffre, R. R. Brooks, J. Lee, and R. D. Reeves, "Sebertiaacuminata: a nickel accumulating plant from New Caledonia," Science, vol. 193, p. 579, 1976.

[180] A. J. M. Baker, R. D. Reeves, and A. S. M. Hajar, "Heavy metal accumulation and tolerance in British populations of the metallophyte Thlaspi caerulescens J \& C Presl (Brassicaceae)," The New Phytologist, vol. 127, no. 1, pp. 61-68, 1994.

[181] R. D. Reeves and R. R. Brooks, "Hyperaccumulation of lead and zinc by two metallophytes from mining areas of central Europe," Environmental Pollution Series A: Ecological and Biological, vol. 31, no. 4, pp. 277-285, 1983.

[182] R. L. Chaney, J. S. Angle, C. L. Broadhurst, C. A. Peters, R. V. Tappero, and D. L. Sparks, "Improved understanding of hyperaccumulation yields commercial phytoextraction and phytomining technologies," Journal of Environmental Quality, vol. 36, no. 5, pp. 1429-1433, 2007.

[183] A. van der Ent, A. J. M. Baker, R. D. Reeves, A. J. Pollard, and H. Schat, "Hyperaccumulators of metal and metalloid trace elements: Facts and fiction," Plant and Soil, vol. 362, no. 1-2, pp. 319-334, 2013.

[184] L. J. Nicks and M. F. Chambers, "Farming for metals," Mining Environmental Management, vol. 3, pp. 15-18, 1995.

[185] R. D. Reeves, R. R. Brooks, and R. M. McFarlane, "Nickel uptake by Californian Streptanthus and Caulanthus with particular reference to the hyperaccumulator $S$. polygaloides Gray (Brassicaceae)," American Journal of Botany, vol. 68, pp. 708712, 1981.

[186] B. H. Robinson, R. R. Brooks, A. W. Howes, J. H. Kirkman, and P. E. H. Gregg, "The potential of the high-biomass nickel hyperaccumulator Berkheya coddii for phytoremediation and phytomining," Journal of Geochemical Exploration, vol. 60, no. 2, pp. 115-126, 1997.

[187] C. W. N. Anderson, R. B. Stewart, F. N. Moreno et al., "Gold phytomining. Novel developments in a plant-based mining system," in Proceedings of the Gold 2003 Conference : New Industrial Applications of Gold, World Gold Council and Canadian Institute of Mining, Metallurgy and Petroleum, 2003.

[188] R. D. Reeves and A. J. M. Baker, "Studies on metal uptake by plants from serpentine and non-serpentine populations of Thlaspi goesingense Halacsy (Cruciferae)," New Phytologist, vol. 98, no. 1, pp. 191-204, 1984.

[189] B. H. Robinson, R. R. Brooks, and B. E. Clothier, "Soil amendments affecting nickel and cobalt uptake by Berkheya coddii: Potential use for phytomining and phytoremediation," Annals of Botany, vol. 84, no. 6, pp. 689-694, 1999.

[190] J. Lin, W. Jiang, and D. Liu, "Accumulation of copper by roots, hypocotyls, cotyledons and leaves of sunflower (Helianthus annuus L.)," Bioresource Technology, vol. 86, no. 2, pp. 151-155, 2003.

[191] W. Jiang, D. Liu, and W. Hou, "Hyperaccumulation of cadmium by roots, bulbs and shoots of garlic (Allium sativum L.)," Bioresource Technology, vol. 76, no. 1, pp. 9-13, 2001.

[192] S. Wei, Q. Zhou, J. Zhan et al., "Poultry manured Bidens tripartite L. extracting Cd from soil-potential for phytoremediating Cd contaminated soil," Bioresource Technology, vol. 101, no. 22, pp. 8907-8910, 2010.

[193] C. W. N. Anderson, R. R. Brooks, A. Chiarucci et al., "Phytomining for nickel, thallium and gold," Journal of Geochemical Exploration, vol. 67, no. 1-3, pp. 407-415, 1999.
[194] F. A. Msuya, R. R. Brooks, and C. W. N. Anderson, "Chemicallyinduced uptake of gold by root crops: its significance for phytomining," Gold Bulletin, vol. 33, no. 4, pp. 134-137, 2000.

[195] T. Jaffré, Etude Écologique du Peuplementvégétal des Sols Dérivés de Rochesultrabasiques en Nouvelle-Calédonie, vol. 124 of Travaux et Documents de l'ORSTOM, ORSTOM, 1980.

[196] M. Leblanc, D. Petit, A. Deram, B. H. Robinson, and R. R. Brooks, "The phytomining and environmental significance of hyperaccumulation of thallium by Iberis intermedia from southern France," Economic Geology, vol. 94, no. 1, pp. 109-114, 1999.

[197] L. F. Juárez-Santillán, C. A. Lucho-Constantino, G. A. VázquezRodríguez, N. M. Cerón-Ubilla, and R. I. Beltrán-Hernández, "Manganese accumulation in plants of the mining zone of Hidalgo, Mexico," Bioresource Technology, vol. 101, no. 15, pp. 5836-5841, 2010.

[198] B. J. Alloway, Heavy Metals, Blackie and Professional, London, UK, 1995.

[199] C. W. N. Anderson, R. R. Brooks, R. B. Stewart, and R. Simcock, "Harvesting a crop of gold in plants," Nature, vol. 395, no. 6702, pp. 553-554, 1998.

[200] C. W. N. Anderson, R. R. Brooks, R. B. Stewart, and R. Simcock, "Gold uptake by plants," Gold Bulletin, vol. 32, no. 2, pp. 48-58, 1999.

[201] M. Sakakibara, A. Harada, S. Sano, R. S. Hori, and M. Inouhe, "Phytoremediation of heavy metals contaminated by Eleocharis acicularis," in Proceedings of the 12th Symposium Soil Groundwater Contamination Remedies, pp. 545-548, Kyoto, Japan, 2006.

[202] N. T. H. Ha, M. Sakakibara, S. Sano, R. S. Hori, and K. Sera, "The potential of Eleocharis acicularis for phytoremediation: case study at an abandoned mine site," Clean, vol. 37, no. 3, pp. 203-208, 2009.

[203] N. T. H. Ha, M. Sakakibara, and S. Sano, "Accumulation of Indium and other heavy metals by Eleocharis acicularis: an option for phytoremediation and phytomining," Bioresource Technology, vol. 102, no. 3, pp. 2228-2234, 2011.

[204] E. Chmielewská and J. Medved, "Bioaccumulation of heavy metals by green algae Cladophora glomerata in a refinery sewage lagoon," Croatica Chemica Acta, vol. 74, no. 1, pp. 135-145, 2001.

[205] D. Kratochvil and B. Volesky, "Advances in the biosorption of heavy metals," Trends in Biotechnology, vol. 16, no. 7, pp. 291300, 1998.

[206] P. Kujan, A. Prell, H. Šafáŕ, M. Sobotka, T. Řezanka, and P. Holler, "Removal of copper ions from dilute solutions by Streptomyces noursei mycelium. Comparison with yeast biomass," Folia Microbiologica, vol. 50, no. 4, pp. 309-313, 2005.

[207] D. Brady and J. R. Duncan, "Bioaccumulation of metal cations by Saccharomyces cerevisiae," Applied Microbiology and Biotechnology, vol. 41, no. 1, pp. 149-154, 1994.

[208] N. R. Bishnoi and Garima, "Fungus-an alternative for bioremediation of heavy metal containing wastewater: a review," Journal of Scientific and Industrial Research, vol. 64, no. 2, pp. 93-100, 2005.

[209] N. P. Bhatia, A. E. Nkang, K. B. Walsh, A. J. M. Baker, N. Ashwath, and D. J. Midmore, "Successful seed germination of the nickel hyperaccumulator Stackhousia tryonii," Annals of Botany, vol. 96, no. 1, pp. 159-163, 2005.

[210] R. D. Reeves, A. J. M. Baker, A. Borhidi, and R. Berazaín, "Nickel hyperaccumulation in the serpentine flora of Cuba," Annals of Botany, vol. 83, no. 1, pp. 29-38, 1999. 
[211] R. D. Reeves and A. J. M. Baker, "Metal accumulating plants," in Phytoremediation of Toxic Metals: Using Plants to Clean up the Environment, I. Raskin and E. D. Ensley, Eds., pp. 193-229, John Wiley \& Sons, New York, NY, USA, 2000.

[212] J. L. Gardea-Torresdey, J. R. Peralta-Videa, G. de la Rosa, and J. G. Parsons, "Phytoremediation of heavy metals and study of the metal coordination by X-ray absorption spectroscopy," Coordination Chemistry Reviews, vol. 249, no. 17-18, pp. 17971810, 2005.

[213] A. T. Harris and R. Bali, "On the formation and extent of uptake of silver nanoparticles by live plants," Journal of Nanoparticle Research, vol. 10, no. 4, pp. 691-695, 2008.

[214] V. Sheoran, A. S. Sheoran, and P. Poonia, "Phytomining: a review," Minerals Engineering, vol. 22, no. 12, pp. 1007-1019, 2009.

[215] V. Sheoran, S. Sheoran, and A. P. Poonia, "Phytomining of gold: a review," Journal of Geochemical Exploration, vol. 128, pp. 4250, 2013.

[216] V. Wilson-Corral, C. W. N. Anderson, and M. RodriguezLopez, "Gold phytomining: a review of the relevance of this technology to mineral extraction in the 21st century," Journal of Environmental Management, vol. 111, pp. 249-257, 2012.

[217] S. Mann, Biomineralization, Oxford University Press, Oxford, UK, 2002.

[218] I. C. Gebeshuber, "Biomineralization in marine organisms: status, challenges and prospects for biotechnology," in Springer Handbook of Marine Biotechnology, S.-K. Kim, Ed., pp. 12831304, Springer, New York, NY, USA, 2014.

[219] G. A. Mansoori, T. F. George, G. Zhang, and L. Assoufid, "Molecular building blocks for nanotechnology," in Molecular Building Blocks for Nanotechnology: From Diamondoids to Nanoscale Materials and Applications, vol. 111, Springer, New York, NY, USA, 2007.

[220] V. K. Sharma, R. A. Yngard, and Y. Lin, "Silver nanoparticles: green synthesis and their antimicrobial activities," Advances in Colloid and Interface Science, vol. 145, no. 1-2, pp. 83-96, 2009.

[221] M. Zhou, Z. Wei, H. Qiao, L. Zhu, H. Yang, and T. Xia, "Particle size and pore structure characterization of silver nanoparticles prepared by confined arc plasma," Journal of Nanomaterials, vol. 2009, Article ID 968058, 5 pages, 2009.

[222] S. R. Waghmare, M. N. Mulla, S. R. Marathe, and K. D. Sonawane, "Ecofriendly production of silver nanoparticles using Candida utilis and its mechanistic action against pathogenic microorganisms," 3 Biotech, 2014.

[223] Q. H. Tran, V. Q. Nguyen, and A.-T. Le, "Silver nanoparticles: synthesis, properties, toxicology, applications and perspectives," Advances in Natural Sciences: Nanoscience and Nanotechnology, vol. 4, Article ID 033001, 2013.

[224] A. Ravindran, P. Chandran, and S. S. Khan, "Biofunctionalized silver nanoparticles: advances and prospects," Colloids and Surfaces B: Biointerfaces, vol. 105, pp. 342-352, 2013. 

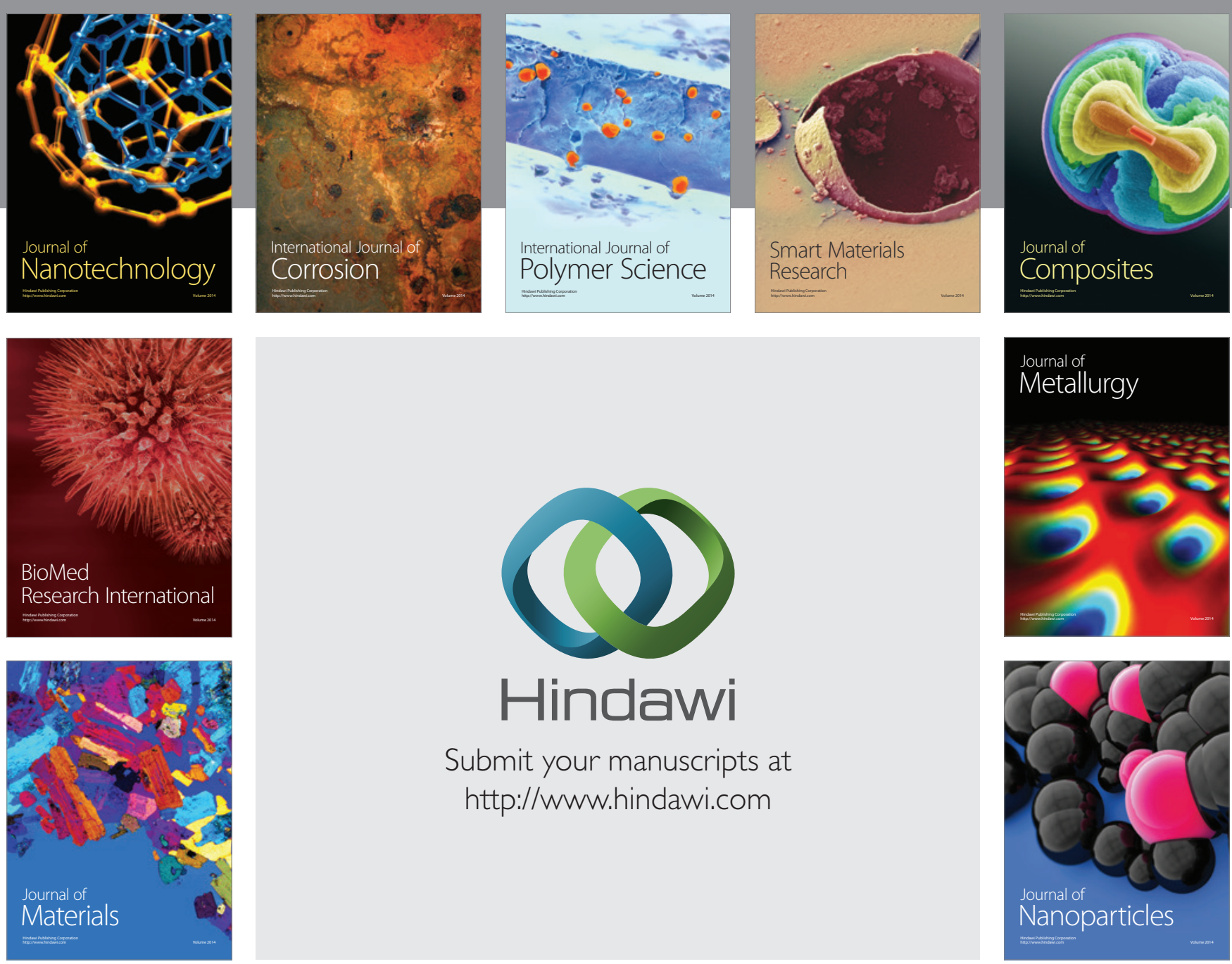

Submit your manuscripts at http://www.hindawi.com
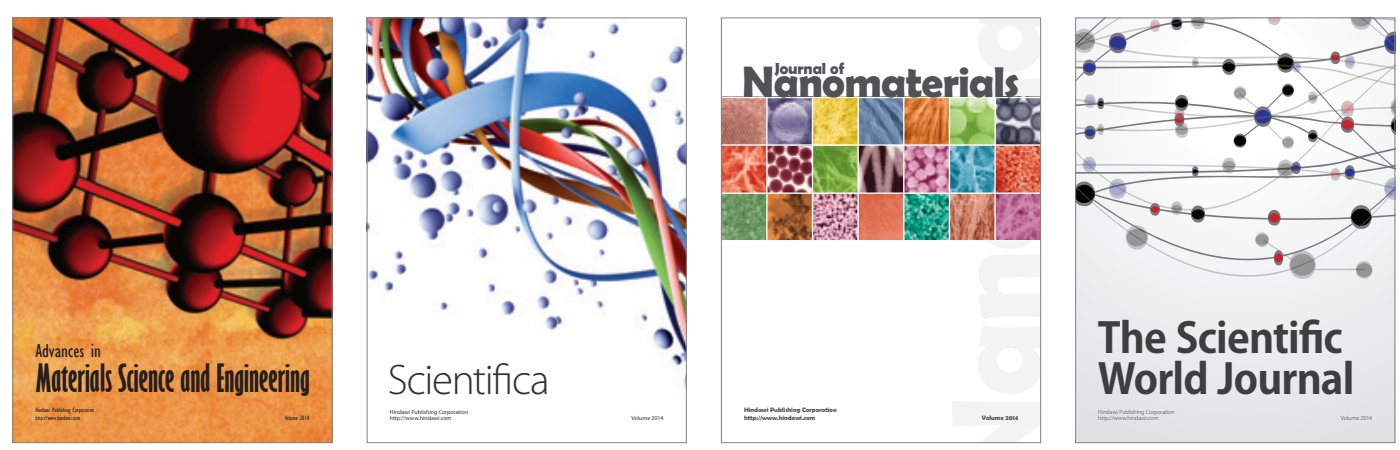

\section{The Scientific World Journal}
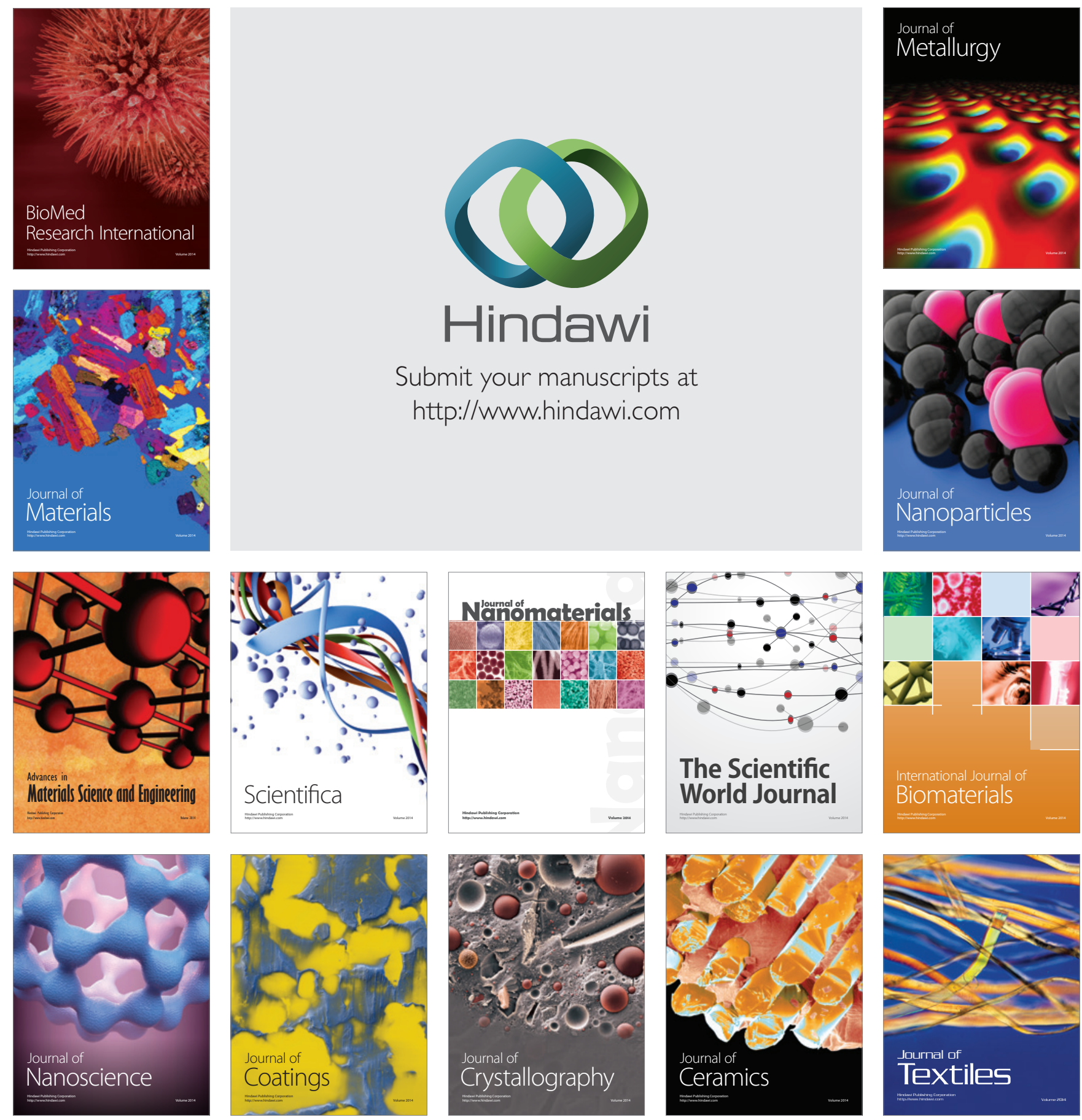